\title{
Identification guide to Nordic aphids associated with mosses, horsetails and ferns (Bryophyta, Equisetophyta, Polypodiophyta) (Insecta, Hemiptera, Aphidoidea)
}

\author{
Anders Christian ALBRECHT \\ Finnish Museum of Natural History - Zoology, University of Helsinki, P. Rautatiekatu 13, FI-00014 \\ Helsinki, Finland. Email: anders.albrecht@helsinki.fi \\ urn:1sid:zoobank.org:author:3835E475-B3F6-4965-A4E6-A3AE55659C86
}

\begin{abstract}
Keys and diagnoses of North European aphids (Hemiptera, Aphidoidea) associated with mosses, horsetails and ferns are given, based on fresh and freeze-dried material. Numerous externally visible and thus informative characters, that are absent in cleared, slide-mounted specimens, such as body shape colours, wax coating and pattern etc., are utilized. Most of the species are illustrated by photographs of live specimens and drawings. Root-feeding species living in the moss layer or otherwise often present in moss samples are also included, even if their hosts were spermatophytes. The combination of colour images and diagnoses, utilizing easily observed characters, allows the identification of a large number of species already in the field, and many more at home with the aid of a stereo microscope. Host plant relationships and association with ants are summarised, including new records. Brief accounts on aphid life cycles, freeze-drying preparation techniques, etc. are also given to support the use of the keys.
\end{abstract}

Keywords. Aphids, Bryophyta, Pteridophyta, identification, photographs.

Albrecht A.C. 2015. Identification guide to Nordic aphids associated with mosses, horsetails and ferns (Bryophyta, Equisetophyta, Polypodiophyta) (Insecta, Hemiptera, Aphidoidea). European Journal of Taxonomy 145: 1-55. http://dx.doi.org/ 10.5852/ejt.2015.145

\section{Introduction}

Aphids are notorious for being difficult to identify and traditionally demanding clearing and mounting procedures before they can be studied, procedures that many beginning students experience as tedious and time-consuming. The preparations include preservation in ethanol, maceration by heating in alcohol and potassium hydroxide $(\mathrm{KOH})$, neutralizing in acetic acid $\left(\mathrm{CH}_{3} \mathrm{COOH}\right)$, rinsing in distilled water, embedding in a suitable medium (e.g., Polyviol, Canada balsam or Euparal) on a microscopic slide, covered by a cover slip and finally drying, preferably in a heated cabinet. Recipes and instructions for the procedures are given in, e.g., Danielsson (1985), Heie $(1980,1986)$ and Blackman \& Eastop (1994, 2014). The clearing and mounting procedures, however, destroy many obvious and useful diagnostic characters, such as shape, colour, wax pattern and grades of sheen and lustre. Disabling these characters forces the identification to rely on counts, measurements and indices based on them. 
This guide is, as far as possible, based on fresh and freeze-dried material, which maximizes the number of characters that can be used, including colouration and wax pattern. The measurements and indices available on slides are naturally also available on freeze-dried specimens, so slide-based keys can very well be used. Just as for slide-mounted material, knowledge of the host plant is of great help for the identification. Most aphids are monophagous or oligophagous, and closely related species usually feed on different plants, which makes plant-based keys fast and easy to use. A clear majority of the species are readily identifiable based on host plant data, diagnoses, colour images of live specimens, fresh or freezedried material and the aid of a good stereo microscope. Often just a glance at a photograph will appear to give the correct identification, but sibling species may be involved, so it should always be kept in mind that host plant association alone is not enough. Descriptions and figures should always be consulted before the decision is made. In some cases fine details need to be studied, and measurements may have to be taken. In most cases the necessary measurements can be taken on fresh and freeze-dried material, without any further processing. Sometimes, however, a water preparation on a slide, e.g., of a leg, is helpful, and in critical cases cleared and mounted specimens are needed. It should be borne in mind that all characters visible in slides are present also in freeze-dried material, and if not directly visible, always can be made so by clearing and mounting the specimen.

The present article is focused on the aphids associated with cryptogams of Finland and Scandinavia, including Iceland, Greenland, The Faroes and Svalbard. Included are also most of the species occurring in adjacent parts of north-eastern Europe, the Baltic region and northern central Europe, including the British Isles. Some species feeding on spermatophytes, but often occurring in moss samples, are also included. Accounts on aphid life cycles, preservation and terminology are also given here, but they are kept short, and more or less limited to subjects needed for using the keys and diagnoses. This article is intended to be followed by papers dealing with aphids feeding on other plants, and the ultimate goal is to cover all aphids occurring in North Europe.

The keys, instead of being dichotomous, consist of multi-character diagnoses and synopses grouping the diagnoses into sections sharing one or a few easily observed characters. Accompanied by photographs and drawings the data given in the diagnoses should in most cases be enough to allow correct identifications, or when that is not the case, to give sufficient reason to doubt the results and seek additional information elsewhere in the literature. As a contrast to keys based on slide material, this article also aims at enabling the student to learn species in advance and to recognise them as they are encountered in the field.

\section{Material and methods}

The host records and distribution data are according to Blackman \& Eastop (1994, 2006, 2014), Heie (1980, 1986, 1992, 1994, 1995, 2004), Holman (2009) and the database of the Finnish Expert Group on Hemiptera (http://biolcoll.utu.fi/hemi/tyoryhma/tyoryhma_eng.htm), comprising most of the aphid data recorded from Finland (predominantly by O. Heikinheimo and myself), with additional records from adjacent countries. The photographs and drawings are original, unless otherwise stated. My own records of hosts are marked with asterisks $\left(^{*}\right)$ in the host lists of the diagnoses and in the host tables (Appendices 1 and 2), as are records by Osmo Heikinheimo and other Finnish collectors whenever I have been able to confirm the relationships (e.g., from Heikinheimo's field notes).

The identifications underlying the figures, keys and diagnoses have all been confirmed by checking against keys and descriptions based on cleared specimens. The diagnoses are kept short, particularly when photographs are available, and the emphasis is on the parthenogenetic morphs, particularly aptera. In many cases, characteristics of juveniles are also included. More elaborate descriptions of all morphs are given in, e.g., Heie $(1980,1986,1992,1994,1995,2004)$ and references therein. The diagnoses are, whenever possible, based on my own observations on fresh and freeze-dried material supplemented by data from Heie (1980, 1986, 1992, 1994, 1995, 2004), Blackman 2010 and Blackman \& Eastop (1994, 
2006, 2014) (generally not cited separately) or other references, cited as used. In addition, valuable information on aphid taxonomy and bibliography can be found in Favret (2015). The plant nomenclature is based on Hill et al. (2006: mosses) and Karlsson \& Agestam (2014: vascular plants). Data on attendant ants are mostly my own (denoted by an asterisk), the nomenclature following Abenius et al. 2012.

\section{Preservation and labelling}

For students who wish to preserve aphid material or build a reference collection without spending excessive time with the slide mounting process, here is an easy recipe for freeze-dried specimens:

1. Collect the aphids in small test tubes or other suitable vials, with or without part of the host plant. A slip of tissue paper may be inserted to absorb excess moisture. Label the vial and close it, e.g., with a cotton wool stopper. Keep the vial out of direct sunshine.

2. At home, put the vials into a container with a layer of desiccant (Silica gel, Rubin gel) on bottom in the freezer $\left(-18^{\circ} \mathrm{C}\right.$ is suitable) and close the container (Fig. 1A). Petri Ahlroth (pers. comm.) uses silica gel cat litter as desiccant, and his aphid specimens are excellent. More material can be added when needed. Some specimens can be pinned on micro-pins and the wings set at this stage. It may be useful to pin the specimens from below, in which case the blunt end of the micro pins may be sharpened (Fig. 1B). Pinned specimens should preferably be mounted on a piece of, e.g., foam polystyrene to support the legs during the drying process. The wings of alatae can also be set (Fig. 1C).

3. After a few months the aphids are dry and ready for the collection, as such in tubes or other vials (Fig. 1D), pinned, or glued to cardboard. Galls usually take at least six months to dry properly. For examples of dry, pinned specimens, see Fig. 1E-G.

To speed up the drying process, vacuum equipment can be used (e.g., Albrecht 1994), but that is by no means necessary.

Please note that in addition to the basic information on the labels (place, date and collector) it is of utmost importance to add information on the aphid's position and occurrence on the plant. Just the name of the host plant is not enough to ascertain a true aphid-host relationship. "Cirsium arvense. Dense colony on upper part of stalk." is a correct host plant statement, whereas "Cirsium arvense" alone denotes a substrate or (the worst scenario) a subsequently added inferred "host" name, and its role as host is not determined. Sadly enough, museum collections consist too often of many inadequately labelled aphid samples, and many temporary substrates may have entered published host lists. An addition of attendant ants is also welcome: "Attended by Lasius niger", preferably accompanied by a couple of preserved ants. If the attending ant species cannot be identified with certainty, as is often the case with, e.g., wood ants (Formica), it is better to leave the species name out instead of implying a certain identification.

\section{Aphid life cycles}

This chapter is intentionally kept very brief. I will just try to give the information needed for using my keys. Most of the information is embedded in the figures. The accounts of life cycles given here are just examples of frequently occurring patterns, and are by no means intended to be complete. For more thorough accounts, see, e.g., Blackman (2014) or Heie (2004). Characteristically, the life cycle comprises one sexual generation consisting of oviparous females and males (sexuales), alternating with one or more parthenogenetic generations. The parthenogenetic females are viviparous (Aphididae) or oviparous (Adelgidae, Phylloxeridae). Except in the Adelgidae, hibernation takes place in the egg stage. Life cycles including both sexual and parthenogenetic generations (complete life cycle) are called a holocycle, whereas cycles lacking the sexual generations are called anholocyclic. Some life cycles involve host alternation where the sexual reproduction and hibernation takes place on one host, the primary host, usually a woody plant, with migration to secondary host(s) in spring, and back in autumn. The secondary hosts are usually herbaceous plants, but migration to roots of trees and shrubs is common 


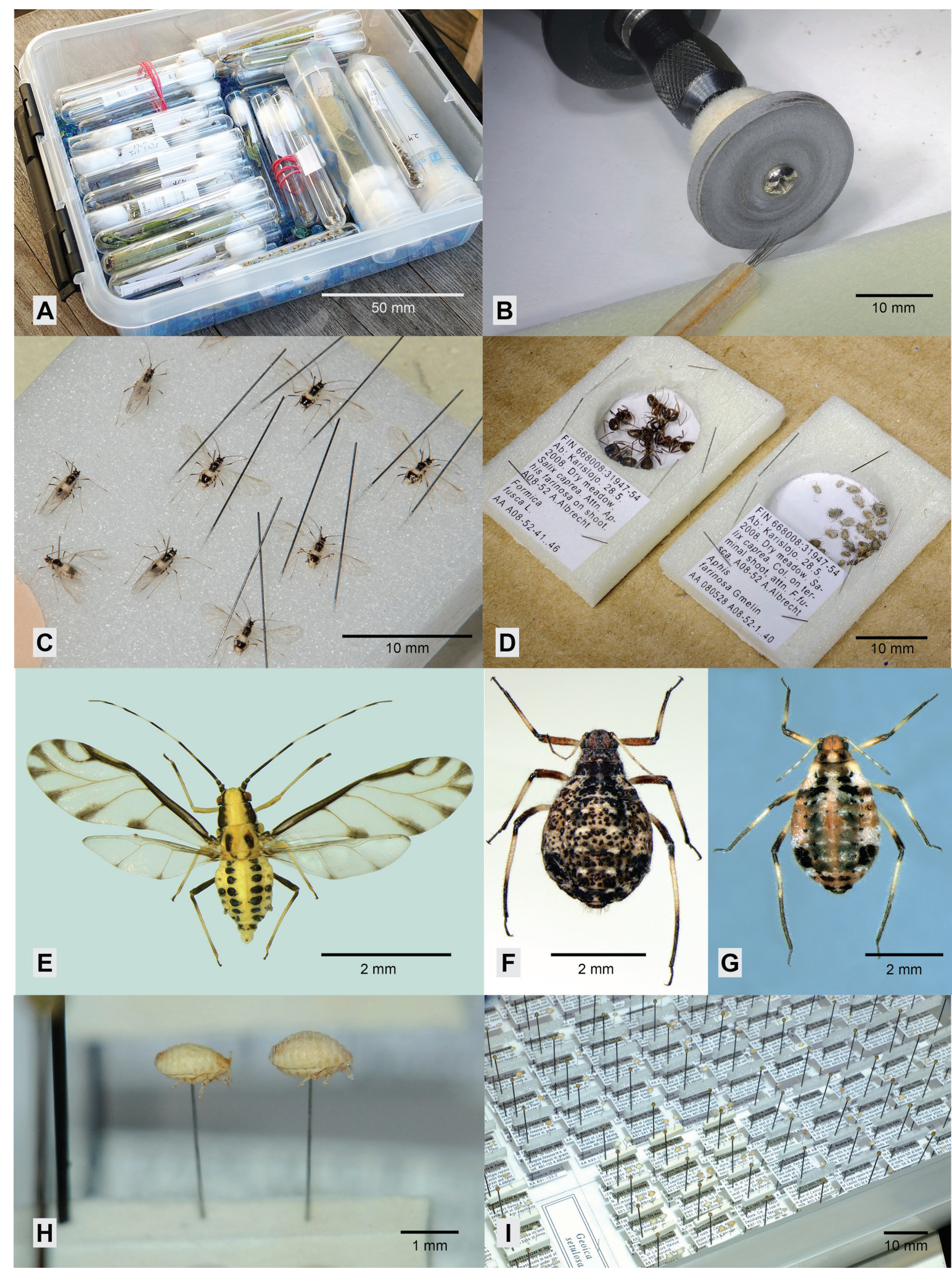

Fig. 1. A. Freeze-drying container with samples and silica-gel on bottom. B. Equipment for sharpening micro pins. C. Foam plate with pinned aphids (Hyperomyzus lampsanae (Börner, 1932)). D. Foam polyurethane storage vials (Formica fusca Linnaeus, 1758 and Aphis farinosa Gmelin, 1790). E-I. Pinned freezedried aphids. E. Eucallipterus tiliae (Linnaeus, 1758). F. Cinara laricis (Hartig, 1839). G. Cinara pruinosa (Hartig, 1841). H-I. Geoica utricularia (Passerini, 1856). 


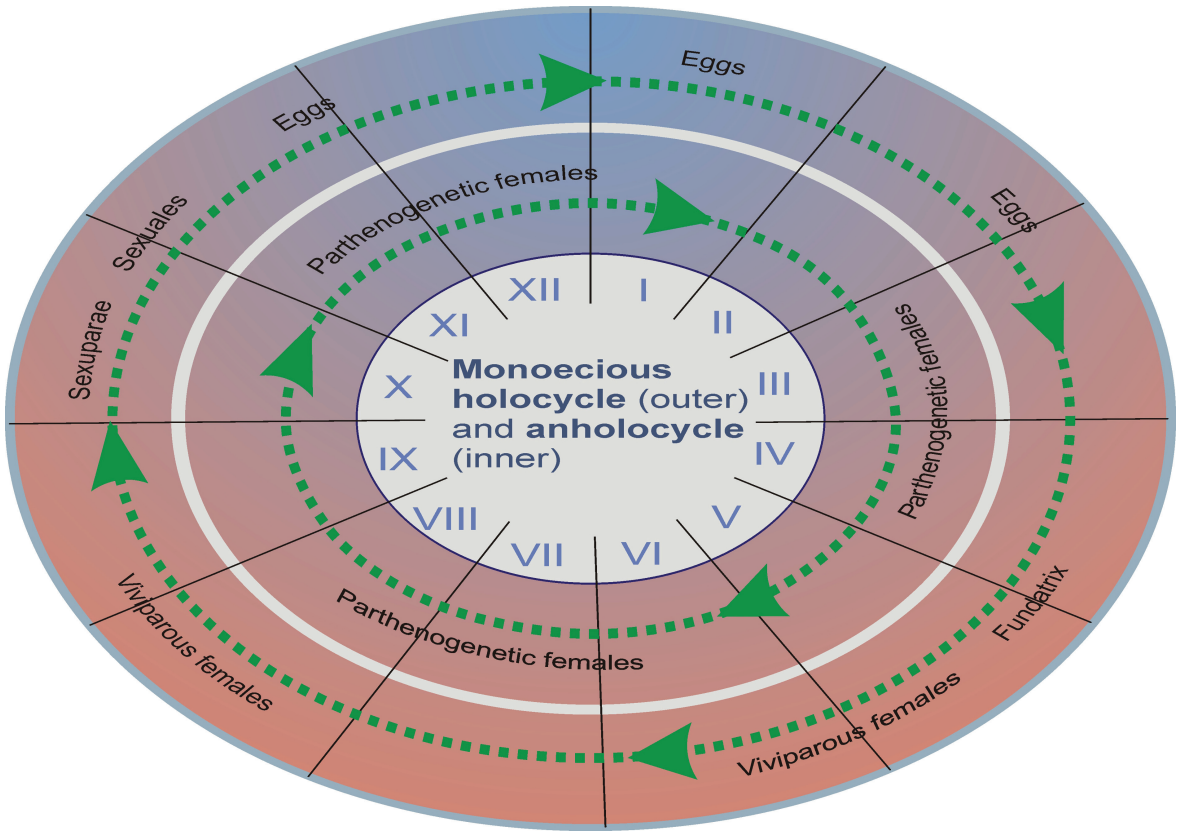

Fig. 2. Monoecious one-year life cycles. In the outer zone an ordinary monoecious holocycle in Aphididae. The fertilized egg overwinters and in spring the first viviparous parhenogenetic generation, the fundatrix (stem-mother) hatches. Upon the fundatrix follows a variable number of viviparous females (viviparae), apterous and/or alate. In autumn (sometimes earlier) sexuparae are born and in turn give birth to oviparous (sexual) females (ovipara) and males, which mate, and the oviparae lay eggs. The inner zone shows an anholocycle, with only parthenogenetic females (viviparous in Aphididae, oviparous in Adelgidae).

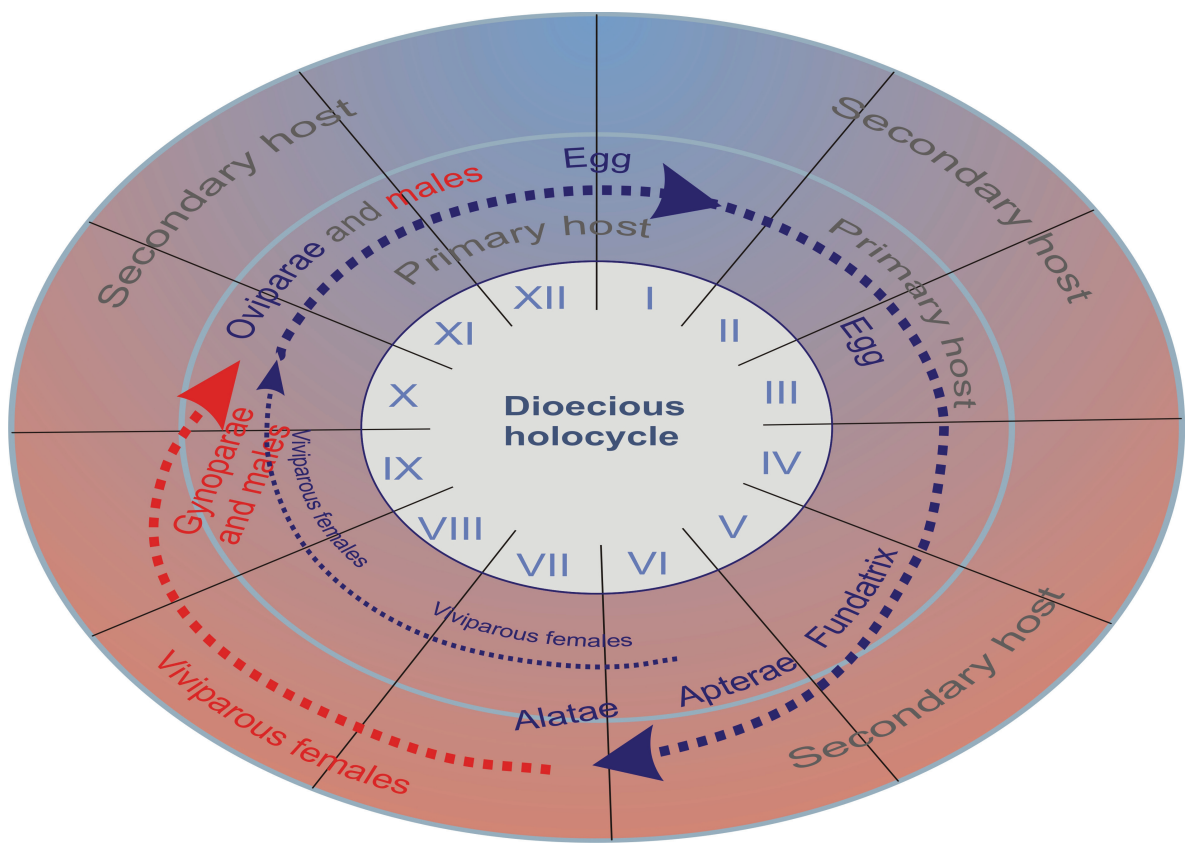

Fig. 3. Dioecious one-year holocycle (Rhopalosiphum padi). The inner zone represents the primary host (bird cherry, Prunus padus and allies), the outer zone the secondary (usually graminoids). The fundatrix gives birth to apterae, which in turn give birth to alatae, most of which migrate to the secondary hosts. In autumn males and gynoparae (viviparae giving birth to oviparae) migrate to the primary host, where mating and egg-laying take place. A small fraction of the viviparae may remain on the primary host throughout the summer. 


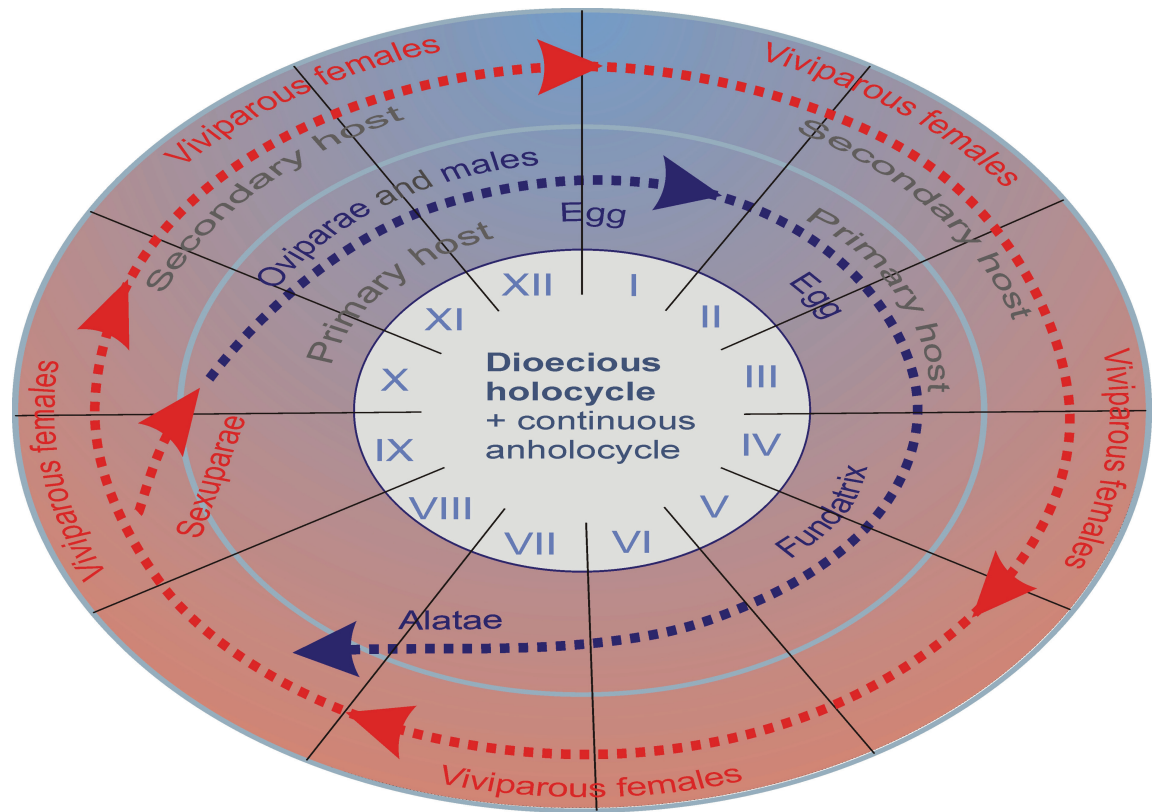

Fig. 4. Dioecious one-year holocycle accompanied by a continuous anholocycle on the secondary host, e.g., Pachypappella lactea (leaf galls on aspen, Populus tremula; roots of spruce, Picea abies) or Tetraneura ulmi (leaf galls on elm, Ulmus; subterraneous parts of grasses, Poaceae). Zones as in Fig. 3. In some years the Finnish populations on the primary hosts (for P. lactea in South Finland) may be more or less absent, and their existence is dependent on the populations on the secondary hosts.

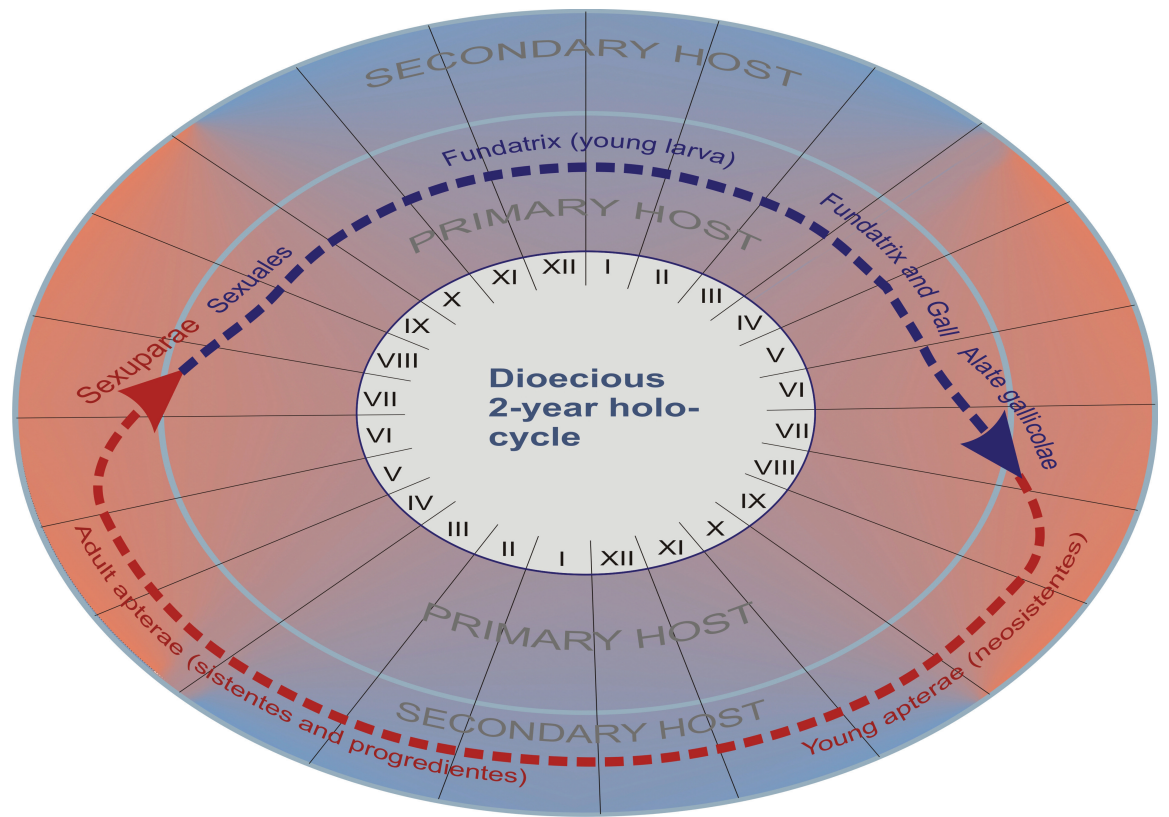

Fig. 5. Dioecious two-year holocycle in Adelgidae, e.g., Adelges laricis (shoot galls on spruce, Picea; needles of larch, Larix). All females oviparous. The fundatrix (hatched from a fertilized egg) overwinters as a larva, and induces the formation of a pineapple-like gall on the primary host. All her offspring are alate (gallicolae) and migrate to the secondary host, where they lay eggs on the needles. The aphids hatching move to the twigs where they hibernate as young larvae (the 'neosistens' stage). In spring they move back to the needles and become adults (sistentes). Their offspring are either alate sexuparae and migrate to spruce, or apterous 'progredientes'. In autumn the sexuparae fly to spruce and lay eggs which become sexual females and males, which mate. The females then lay eggs out of which new fundatrices hatch. 
in Eriosomatinae. Species that complete their life cycle on one host are called monoecious (Fig. 2), whereas species with host alternation are called dioecious (or heteroecious) (Fig. 3). In many species holocycles are accompanied or supported by anholocyclic populations (Fig. 4). Most aphids have oneyear cycles, but also two-year cycles do occur, e.g., in Eriosomatinae (Fordini) and Adelgidae (Fig. 5).

Often used morphological terms are shown in Fig. 6.

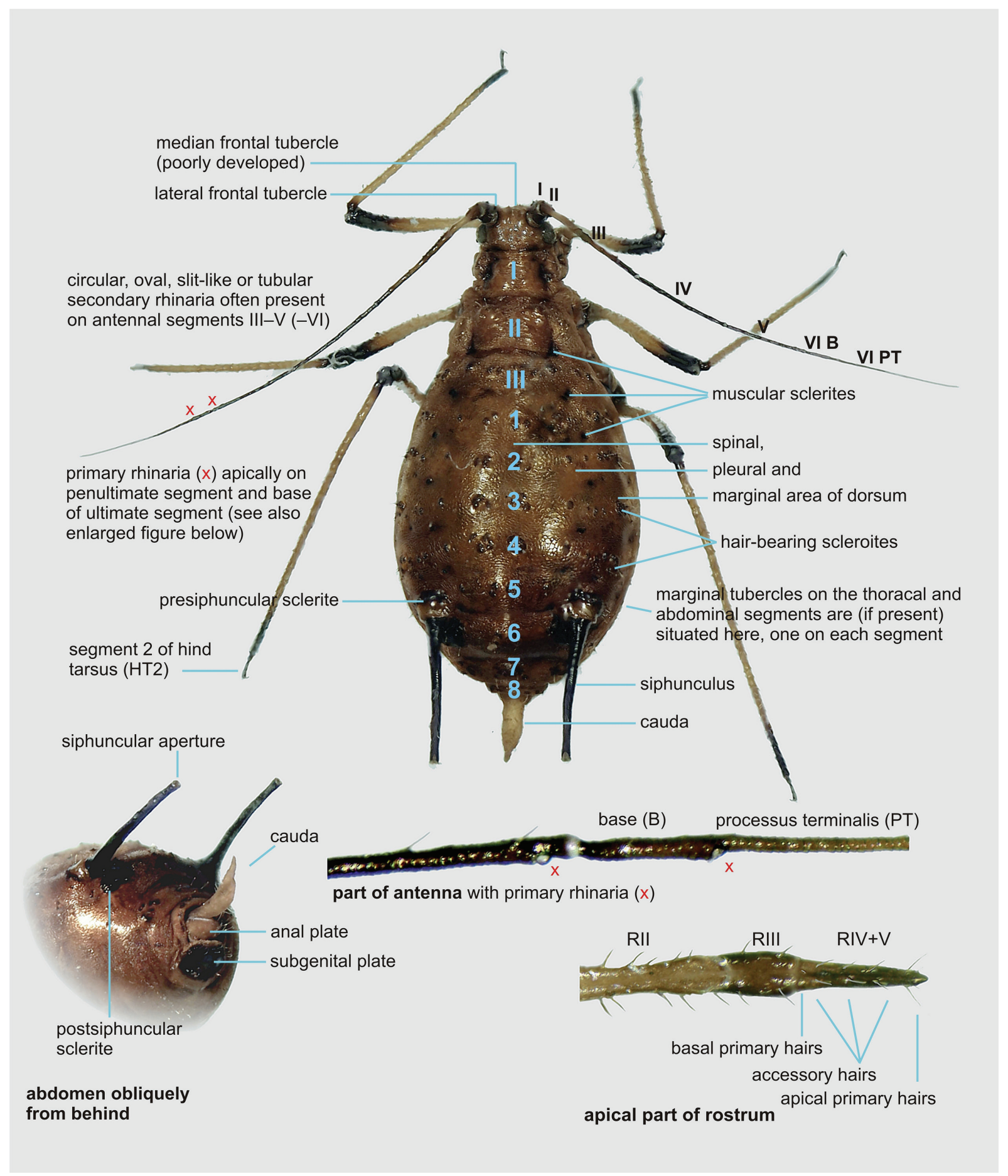

Fig. 6. Often used morphological terms (Uroleucon cirsii (Linnaeus, 1758), freeze-dried specimen.) 


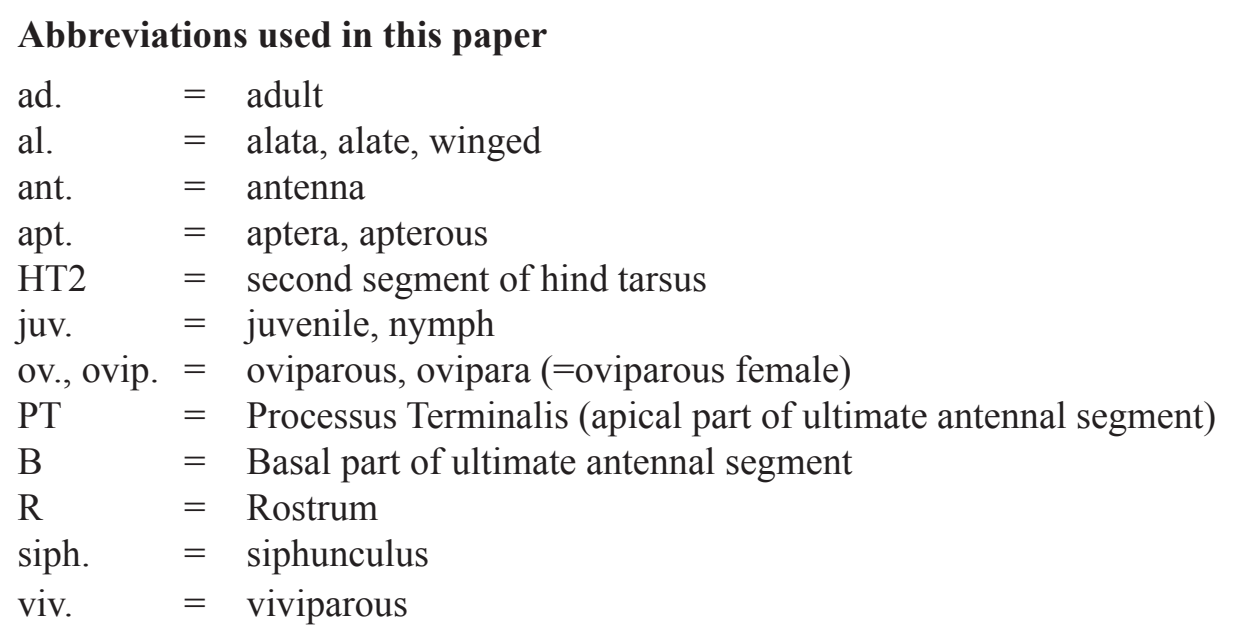

The presence of the species in the Nordic countries is based on Heie (1980, 1982, 1986, 1992, 1994, 1995, 2004) and my own databases. The countries are denoted by letters as follows:

$\mathrm{D}=$ Denmark

$\mathrm{F}=$ Finland

$\mathrm{Fa}=$ Faroes

$\mathrm{Gr}=$ Greenland

$\mathrm{I}=$ Iceland

$\mathrm{N}=$ Norway

$\mathrm{S}=$ Sweden

$\mathrm{Sv}=$ Svalbard

\section{Results}

Phylum Arthropoda von Siebold, 1848

Class Insecta Linnaeus, 1758

Order Hemiptera Linnaeus, 1758

Superfamily Aphidoidea Latreille, 1802

Family Aphididae Latreille, 1802

\section{Synoptic key and diagnoses for aphids on mosses, horsetails and ferns}

For a summary of the host-plant relationships of aphids feeding on mosses, horsetails and ferns, see Appendix 1 and 2. In the diagnoses my own host records and relevant others from the database are denoted by an asterisk (*) after the host name. For geographical and phenological records from Finland, see Albrecht (2010).

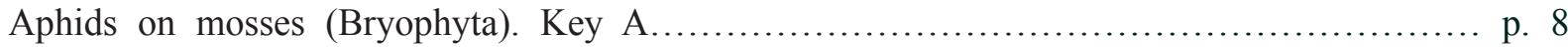

Aphids on horsetails (Equisetophyta). Key B............................................... 30

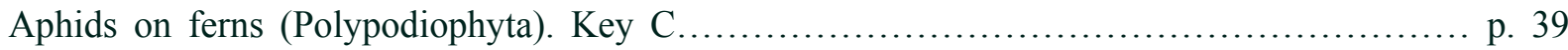

\section{Key A. Aphids on mosses (Bryophyta)}

\section{Synopsis}

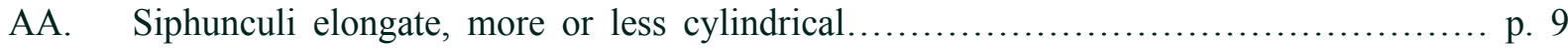

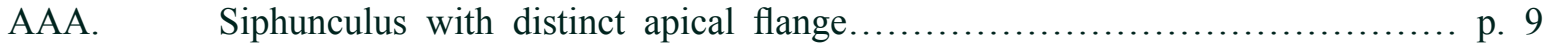

AAB. Siphunculus without flange............................................. p. 14

AABA. Siphuncular aperture terminal.......................................... p. 14

AABB. Siphuncular aperture subterminal........................................ p. 16 
AB. Siphunculi absent or present as pores, at most raised on low cones................... p. 19

ABA. Body extremely flattened, circular or broadly oval............................ p. 19

ABB. Colour pink to orange; siphuncular pores on low cones..................... p. 20

ABC. Colour cream to light brown; dorsum with brown spatulate hairs................ p. 21

ABD. $\quad$ Colour whitish, cream pale green or pale yellow; dorsal hairs pointed........... p. 22

ABDA. Body robustly built, global or ovoid, $0.5-1.5 \mathrm{~mm}$. Tarsi with segments fused (practically 1-segmented); antennae 4-5-segmented. Legs, antennae and rostrum short

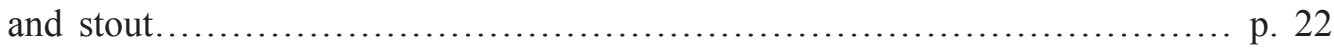

ABDB. Body elongate, 1-2.5 mm. Legs, antennae and rostrum more slender; tarsi 1-2-

segmented; antennae 5-6-segmented................................... p. 25

ABDBA. RIV+V with a broad, distinct, pale subapical zone. Head without wax gland plates

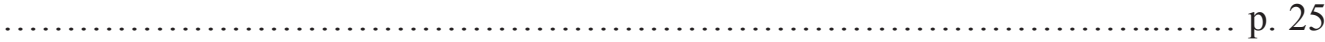

ABDBB. Pale subapical zone on RIV+V narrow, indistinct or absent. Wax glands may be present on head.

AA. Siphunculi elongate, more or less cylindrical

AAA. Siphunculus with distinct apical flange

Subfamily Aphidinae Latreille, 1802

Tribe Macrosiphini Wilson, 1910

Genus Decorosiphon Börner, 1939

Decorosiphon corynothrix Börner, 1939

Fig. 7

\section{Diagnosis}

Apterae 1.2-1.7 mm, shiny olive, brownish yellow or reddish brown, juveniles green-olive brown, with whitish wax dusting, the rupture lines (which break at moulting) exceptionally distinct, due to denser wax coating. Antennae longer than body. Siphunculi strongly swollen distally, with well-developed apical flange. Hairs on body and appendages very long, with spatulate distal part. Ad. and juv. can be found all the year. Peat bogs, damp places in coniferous forests, also deciduous forests. Often on Polytrichum interspersed in Sphagnum tussocks. Monoecious, seems to prefer Polytrichaceae. Not antattended.

\section{Recorded hosts}

Hylocomiaceae: Rhytidiadelphus squarrosus; Polytrichaceae: Atrichum undulatum*, Polytrichastrum formosum, Polytrichum commune, juniperinum, strictum*.

\section{Distribution}

D F N S.

Genus Myzodium Börner, 1949

Myzodium modestum (Hottes, 1926)

Fig. 8

\section{Diagnosis}

Apterae 1.3-1.7 mm, shape Myzus-like, bronze to bronzy black; dorsal cuticle heavily sclerotized, rugose; thinly wax-covered below. Juveniles paler, with shorter body, smoother dorsum and more extensive wax dusting, also dorsally. Frontal tubercles well developed, rounded, nodulose. Siphunculi slightly s-curved, with distinct apical constriction and flange. Aduts and juveniles can be found all year. Peat 
bogs, damp depressions in spruce and pine forests, overhanging moss on rock margins. Monoecious. Not ant-attended.

\section{Recorded hosts}

Bryaceae: Pohlia; Grimmiaceae: Racomitrium; Polytrichaceae: Atrichum undulatum, Polytrichum commune*; Sphagnaceae: Sphagnum (perhaps only interspersed on other mosses).

\section{Distribution}

F Gr S.

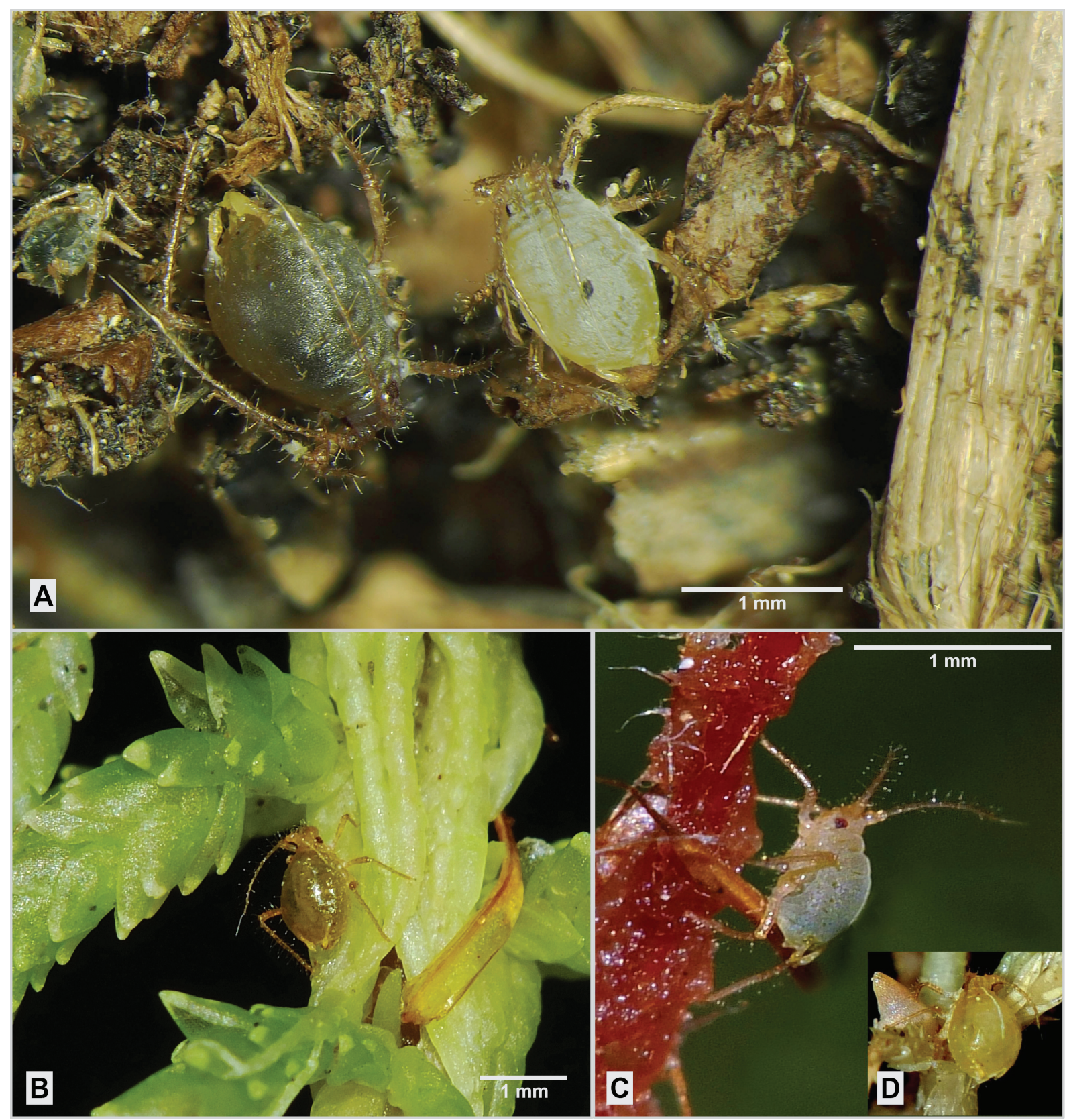

Fig. 7. Decorosiphon corynothrix Börner, 1939. A. Apt. and juv. in Polytrichum commune sample. B. Apt. on Sphagnum magellanicum (with interpersed Polytrichum strictum). C. Apt. juv. on Polytrichum commune. D. Apt. juv. on S. magellanicum, showing rupture line. 


\section{ALBRECHT A.C., Identification guide to Nordic aphids}

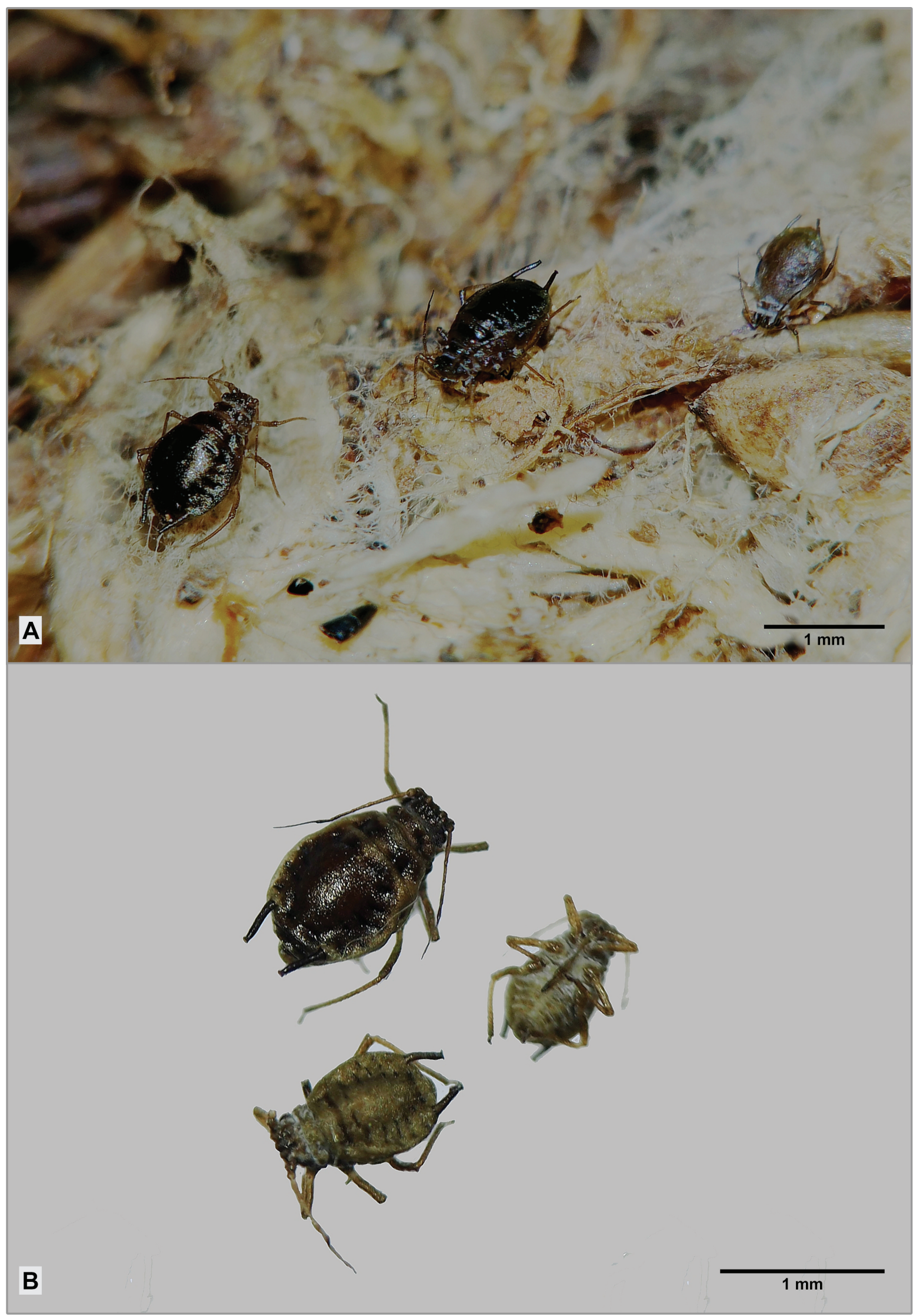

Fig. 8. Myzodium modestum (Hottes, 1926). A-B. Apt. and juv. from Polytrichum commune sample. 
Genus Pseudacaudella Börner, 1950

Pseudacaudella rubida (Börner, 1939)

Fig. 9

\section{Diagnosis}

Apterae $0.7-1.2 \mathrm{~mm}$, shiny green, grey-green, olive or brown, sometimes with rusty patches. Halfgrown juveniles often brownish yellow. Adult apterae with transverse, partly fused, segmental sclerites on thorax and abdomen. Wax-dusted between sclerites and ventrally. Hibernating juveniles dark olive or purple, covered in a thick, easily cracking wax coating. Frontal tubercles undeveloped. Siphunculi with distinct apical constriction and flange. Can be found all year, during the cold season as hibernating nymphs. A ubiquitous species, occurring on a wide range of mosses on dry rock and stones, on the

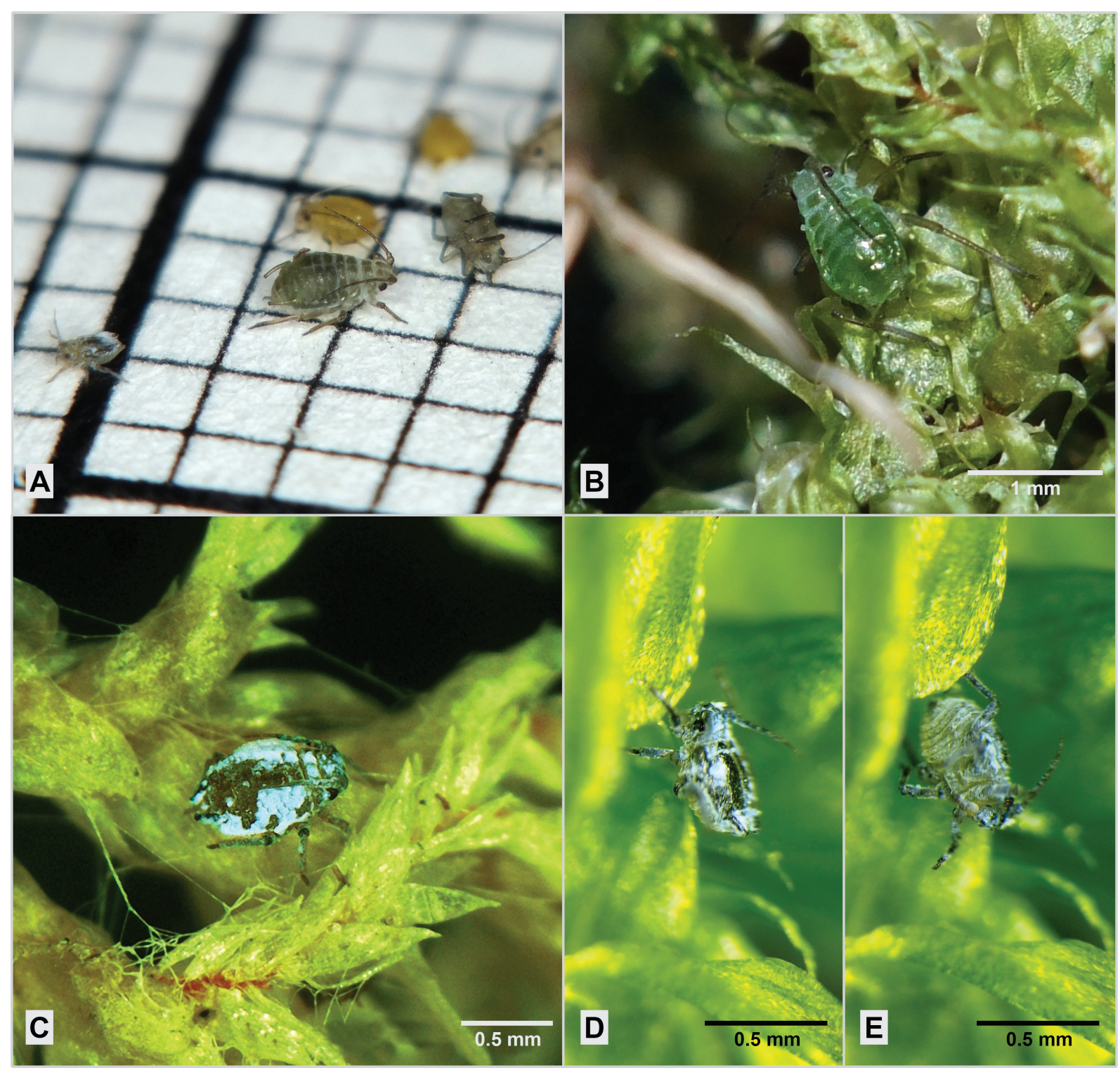

Fig. 9. Pseudacaudella rubida (Börner, 1939). A. Apt. and juv. from Hylocomium splendens sample (grid $1 \mathrm{~mm}$ ). B. Apt. and C. hibernating juv. on Pleurozium schreberi. D-E. Hibernating juv on Calliergon cordifolium. 
forest floor and in damp depressions of spruce and pine forests, fallow fields, deciduous forests, even submerged in forests swamps. Monoecious. Not ant-attended.

\section{Recorded hosts}

Amblystegiaceae:Sanioniauncinata*;Brachytheciaceae:Brachytheciumalbicans*,Pseudoscleropodium purum; Sciuro-hypnum oedipodium*; Calliergonaceae: Calliergon cordifolium*; Climaciaceae: Climacium dendroides; Dicranaceae: Dicranum; Grimmiaceae: Racomitrium lanuginosum*; Hylocomiaceae: Hylocomium splendens*, Pleurozium schreberi*, Rhytidiadelphus squarrosus*; Hypnaceae: Calliergonella cuspidata; Mniaceae: s.lat.; Polytrichaceae: Polytrichum commune*; Sphagnaceae: Sphagnum magellanicum*, recurvum; Thuidiaceae: Thuidium tamariscinum.

\section{Distribution}

D F S.

Genus Cryptaphis Hille Ris Lambers, 1947

Cryptaphis poae (Hardy, 1850)

Fig. 10

\section{Diagnosis}

Apterae 1.3-2.0 mm, shiny, greyish, olive, green or yellowish with brownish markings, to brownish black. Body hairs long, stiff, capitate. Siphunculi straight, with apical flange. Monoecious. Feeds on grasses at or below soil level or in moss tufts, and is sometimes found in moss samples.

\section{Distribution}

D F N S.

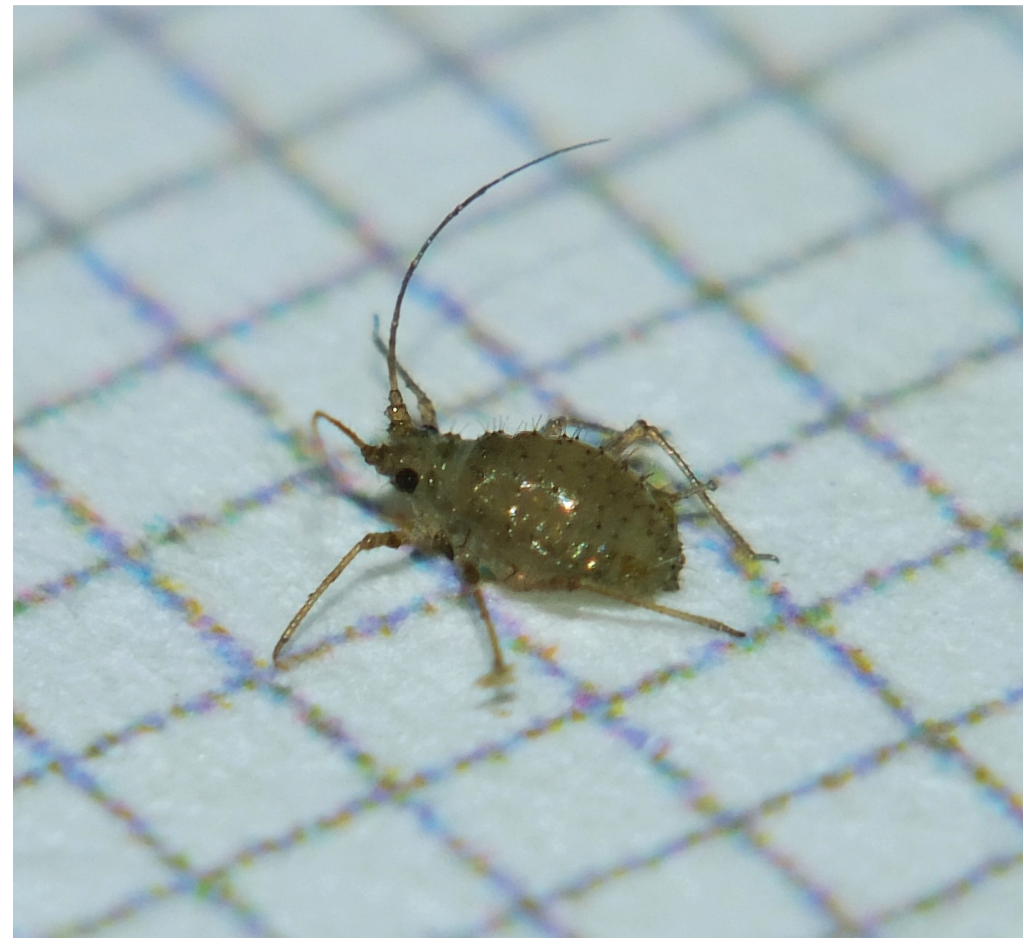

Fig. 10. Cryptaphis poae (Hardy, 1850). Apt. from Rhytidiadelphus squarrosus sample. Grid $1 \mathrm{~mm}$. 
AAB. Siphunculus without flange

AABA. Siphuncular aperture terminal

Genus Jacksonia Theobald, 1923

Jacksonia papillata Theobald, 1923

Fig. 11

\section{Diagnosis}

Diagnosis based on Heie (1994, 2004). Apterae 1.3-1.9 mm, green-olive-brown-reddish. Cuticle rough, squamous or nodulose, particularly on head and antennae. Antennal tubercles well developed, their inner sides converging. Siphunculi squamose, from a thick base narrowing to a slender apical half; aperture small, terminal. Monoecious. Lives on basal parts of grasses and may, in addition to grasses, also feed on mosses.

\section{Recorded hosts}

Holman (2009) reports Hyocomium armoricum and Hypnum cupressiforme (Hypnaceae) as hosts and Heie (2004) Bryum pallens (Bryaceae).

\section{Distribution}

D Fa I N S.

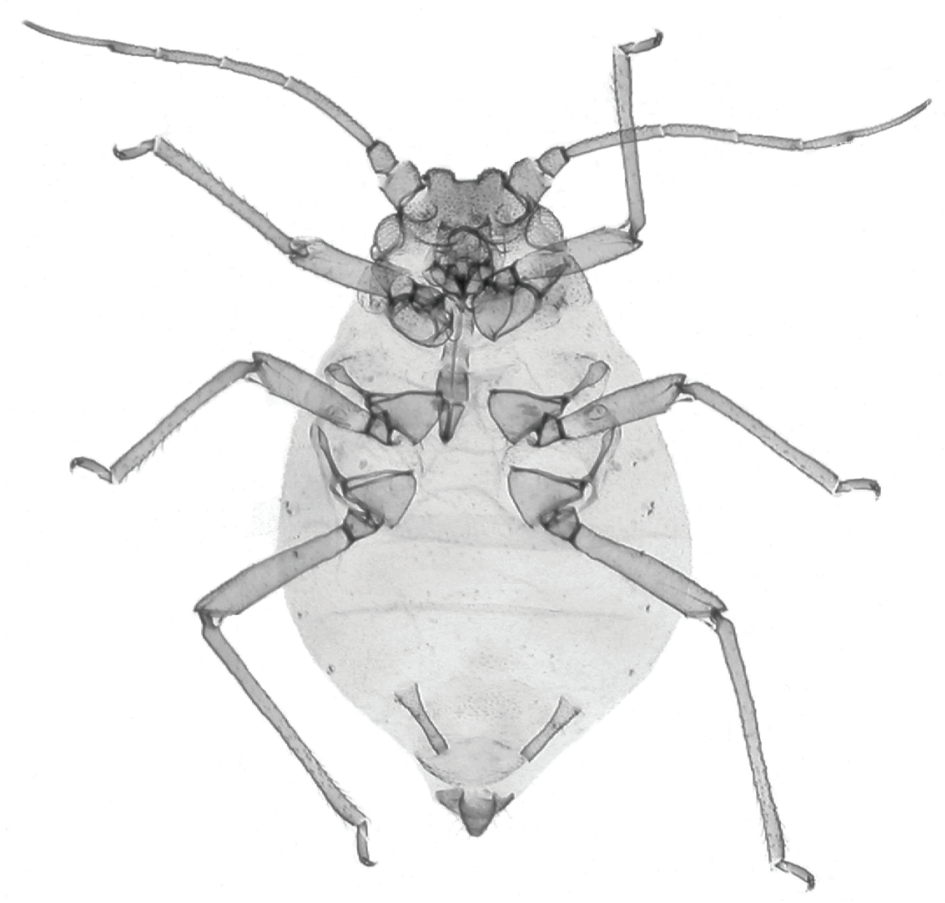

Fig. 11. Jacksonia papillata Theobald, 1923. Aptera (photo Roger Blackman, from Blackman 2010, with license from The Royal Entomological Society). 
Genus Muscaphis Börner, 1933

Subgenus Muscaphis Börner, 1933

Muscaphis musci Börner, 1933

Fig. 12

\section{Diagnosis}

Diagnosis based on Blackman \& Eastop (2014) and Heie (2004). Apterae 0.5-1.0 mm, shiny, greyish yellow, pale brown or dark olive. Siphunculi reddish brown, cylindrical; apex truncate without constriction or flange; aperture terminal. Monoecious?

\section{Recorded hosts}

Amblystegiaceae: Amblystegium; Hypnaceae: Calliergonella; Brachytheciaceae: Brachythecium rutabulum; Brachytheciastrum velutinum, Eurhynchium, Pseudoscleropodium purum; Bryaceae: Bryum; Hylocomiaceae: Hylocomium; Plagiomniaceae: Plagiomnium undulatum; Polytrichaceae: Atrichum undulatum, Polytrichum commune; Pottiaceae: Barbula, Tortula muralis; Calliergonaceae: Calliergon.

\section{Distribution}

D.

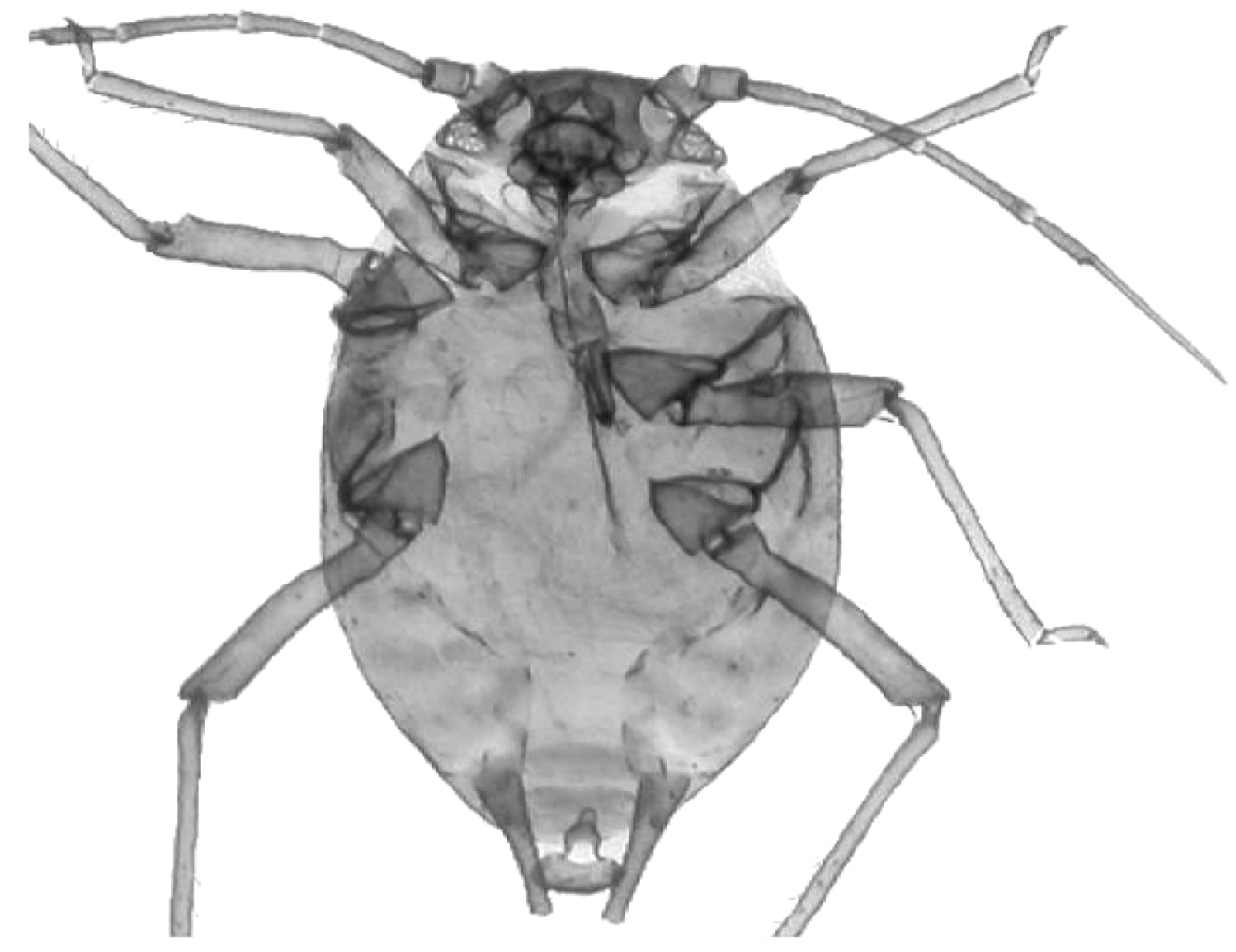

Fig. 12. Muscaphis musci Börner, 1933. Aptera with siphunculus. (photo Roger Blackman, from Blackman 2010, with license from The Royal Entomological Society). 
AABB. Siphuncular aperture subterminal

Subgenus Aspidaphium Börner, 1933

Muscaphis escherichi (Börner, 1939)

Fig. 13

\section{Diagnosis}

Apterae $0.7-1 \mathrm{~mm}$, shiny red-brown, ochreous or olive brown. Legs and antennae slightly paler. Dorsum reticulate, abdominal mid-dorsum fairly smooth, siphunculi squamose. Siphunculi narrowly conical, slightly dorsoventrally flattened, tapering towards a rounded apex; aperture small, subapical. PT/B $=0.6-1.16 ; \mathrm{RIV}+\mathrm{V} / \mathrm{HT} 2=1.2-1.5$. Shady broad-leaved, mixed and coniferous forests, mesotrophic meadows. Can be found all year. Monoecious. Not ant-attended.

\section{Recorded hosts}

Brachytheciaceae: Sciuro-hypnum oedipodium*, Cirriphyllum piliferum*, Kindbergia praelonga (syn. Eurhynchium praelongum), Pseudoscleropodium purum; Bryaceae: Pohlia, Rhodobryum roseum*; Dicranaceae: Dicranum; Hylocomiaceae: Pleurozium schreberi*, Rhytidiadelphus loreus, R. squarrosus; Hypnaceae: Calliergonella cuspidata, Hypnum cupressiforme, Ptilium crista-castrensis; Mniaceae: Mnium hornum; Plagiomniaceae: Plagiomnium affine*, P. rostratum, P. undulatum; Plagiotheciaceae: Plagiothecium laetum (see below).

\section{Distribution}

D F N S.

\section{Note}

The question of whether the moss-feeding $M$. escherichi represents the secondary host generations of the Sorbus-feeding M. drepanosiphoides (Börner, 1939), which would make the two taxa synonymous (Blackman \& Eastop 2014), has not yet been definitely resolved, and is awaiting results from molecular analyses. Until then, I prefer to continue regarding the two taxa as separate species, because they are morphologically distinctive. Among other characteristics are the siphunculi, which are generally quite constant throughout the parthenogenetic morphs. In the Sorbus-feeding fundatrix and alatae they are long, black and truncate, with a large terminal aperture. The transfer experiments of $M$. drepanosiphoides from Sorbus to Plagiothecium laetum performed by Stekolshchikov \& Shaposhnikov (1993) would, however, give support for the synonymy.

Muscaphis cuspidata (Stroyan, 1955)

Fig. 14

\section{Diagnosis}

Apterae $0.7-1 \mathrm{~mm}$, dark greenish brown to black, abdominal dorsum and siphunculi black, legs brown. Dorsum reticulate, siphunculi conical, distinctly dorsoventrally flattened, squamose-papillose, aperture small, subapical. PT/B $=1.2-1.5, \mathrm{RIV}+\mathrm{V} / \mathrm{HT} 2=0.9-1.15$. Can be found all the year round. Pond and stream margins, often submerged. Monoecious. Not ant-attended.

\section{Recorded hosts}

Amblystegiaceae: Drepanocladus aduncus; Brachytheciaceae: Brachythecium rivulare*; Hypnaceae: Calliergonella cuspidata. 
ALBRECHT A.C., Identification guide to Nordic aphids

\section{Distribution}

F.

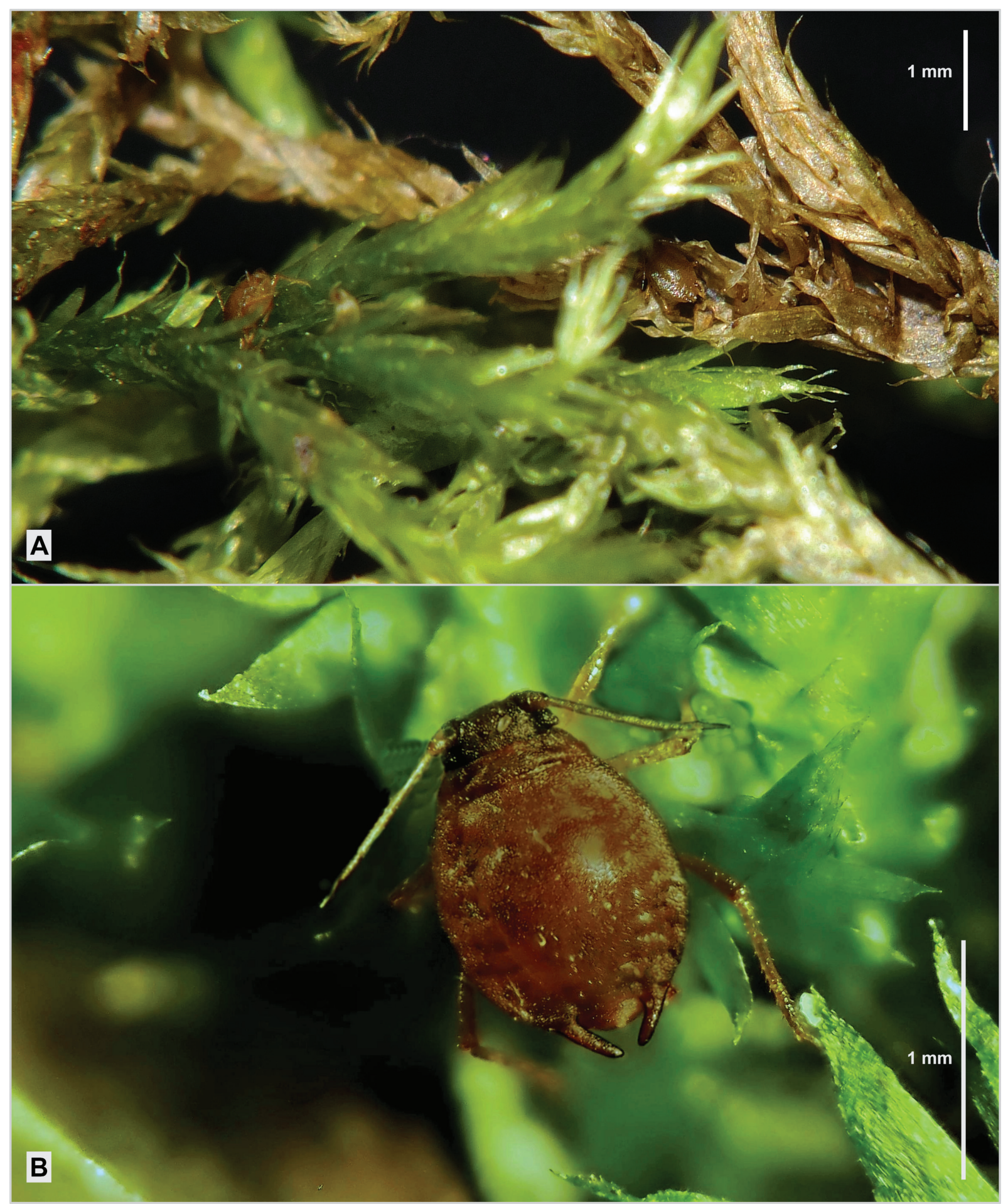

Fig. 13. Muscaphis escherichi (Börner, 1939). A. Apt. on Cirriphyllum piliferum. B. Apt. on Sciurohypnum oedipodium. 


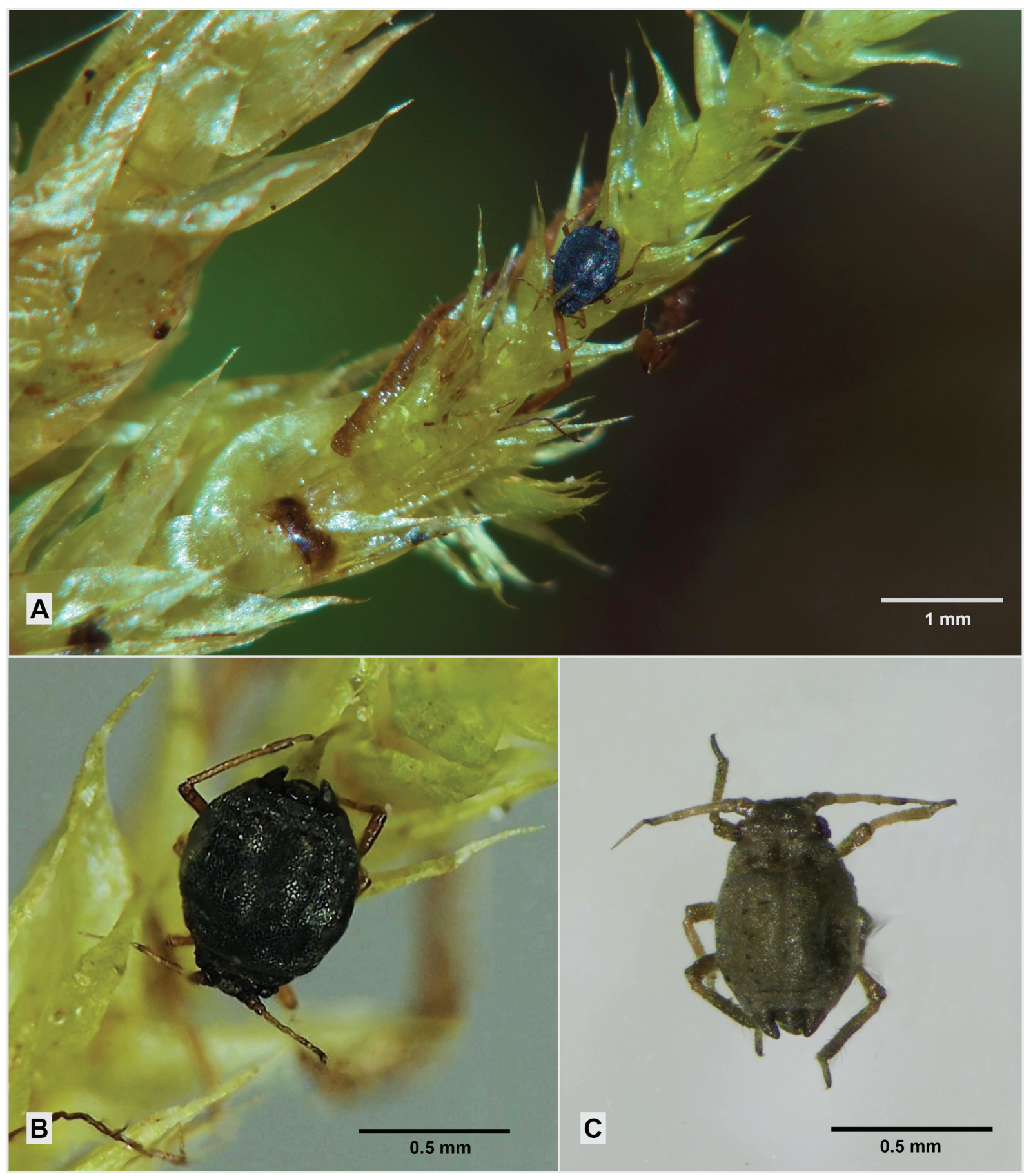

Fig. 14. Muscaphis cuspidata (Stroyan, 1955). A-B. Apt. on Brachythecium rivulare. C. Ovip on Brachythecium rivulare. 
ALBRECHT A.C., Identification guide to Nordic aphids

AB. Siphunculi absent or present as pores, at most raised on low cones

ABA. Body extremely flattened, circular or broadly oval

Subfamily Hormaphidinae

Tribe Hormaphidini

Genus Hormaphis Osten-Sacken, 1861

Hormaphis betulae (Mordvilko, 1901)

Fig. 15

\section{Diagnosis}

Apterae 1-2 mm, pale yellow, circular, flat; older juveniles and adults on secondary host with marginal wax rim. Dioecious. Alternates between witch-hazel Hamamelis (Hamamelidaceae) and birch Betula

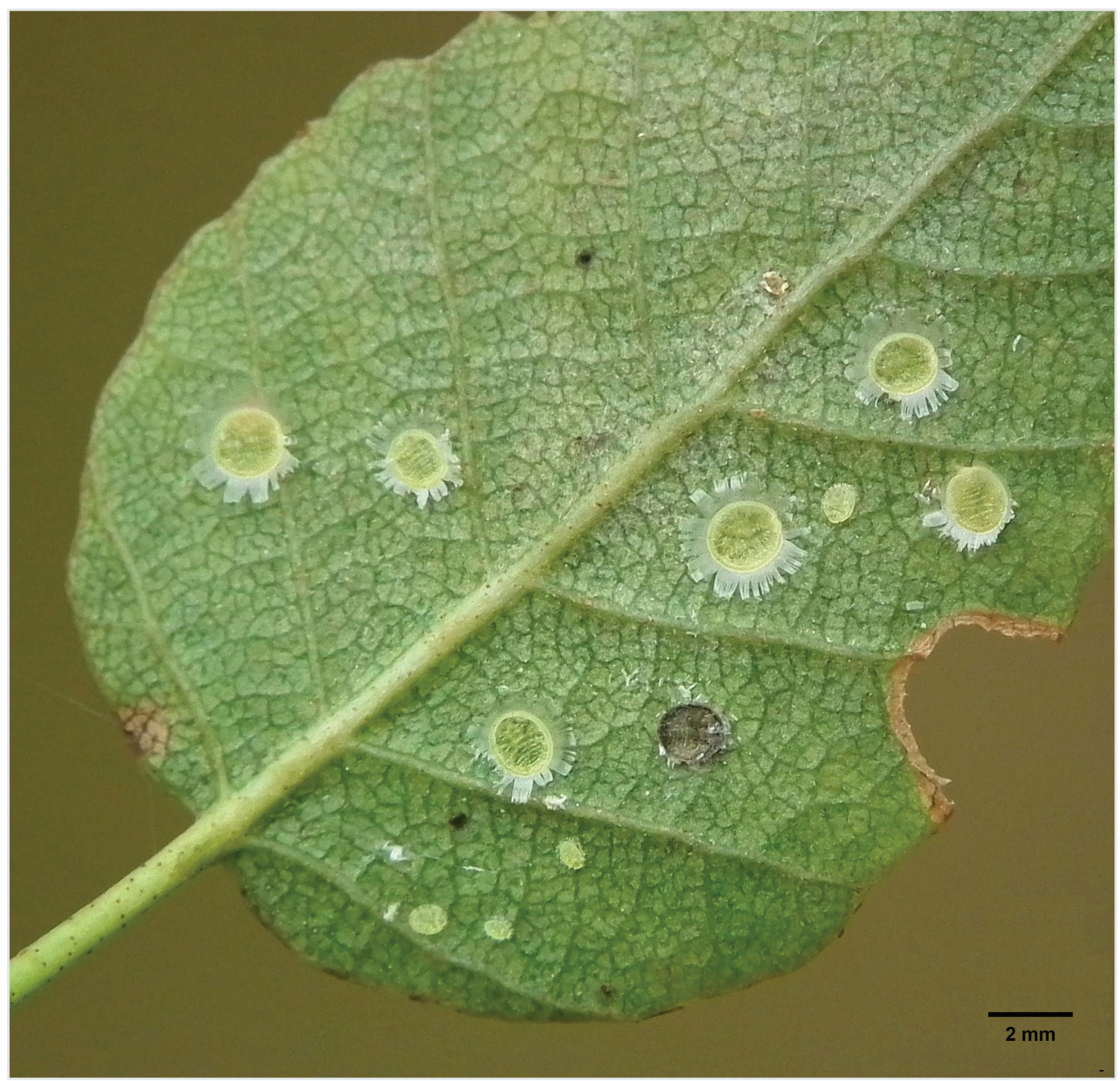

Fig. 15. Hormaphis betulae (Mordvilko, 1901). Apt. (ad. and juv.) on Betula pubescens. 
(Betulaceae). Anholocyclic in Northern Europe, living on birch. Overwintering in the moss layer of mixed coniferous forests and bogs, and during the cold season seen in moss samples.

\section{Distribution}

F.

ABB. Colour pink to orange; siphuncular pores on low cones

Subfamily Eriosomatinae

Tribe Eriosomatini

Genus Tetraneura Hartig, 1841

Tetraneura ulmi (Linnaeus, 1758)

Fig. 16

\section{Diagnosis}

Apterae $1.5-3 \mathrm{~mm}$, pink, orange or purple, with a thin iridescent wax layer that is easily worn off. Siphuncular pores elevated on low cones. Dioecious. Alternating between elm Ulmus (Ulmaceae) and

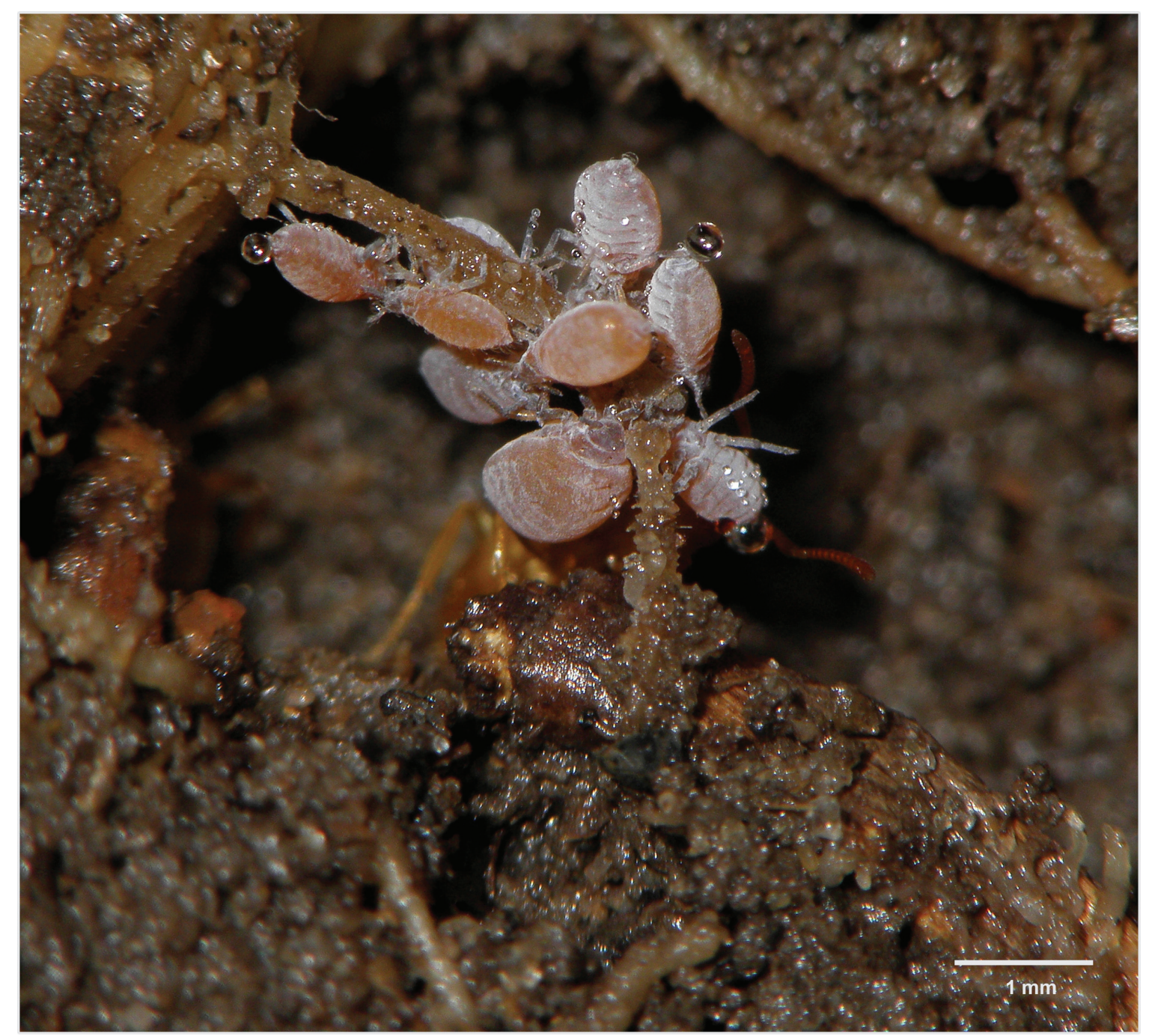

Fi. 16. Tetraneura ulmi (Linnaeus, 1758). Apt. and juv. on grass root. 
ALBRECHT A.C., Identification guide to Nordic aphids

grass roots (Poaceae). Anholocyclic populations on secondary hosts common all year, and particularly juveniles are often seen in moss samples. Often in association with ants.

\section{Distribution}

D F N S.

ABC. Colour cream to light brown; dorsum with brown spatulate hairs

\section{Tribe Fordini}

Genus Geoica Hart, 1894

Geoica utricularia (Passerini, 1856)

Fig. 17

\section{Diagnosis}

Apterae 1.2-2.2 mm, cream to light brown, dusted with white wax. Legs and antennae short and stout, tarsi two-segmented. Body with numerous brown spatulate hairs. Dioecious, alternating between leaf

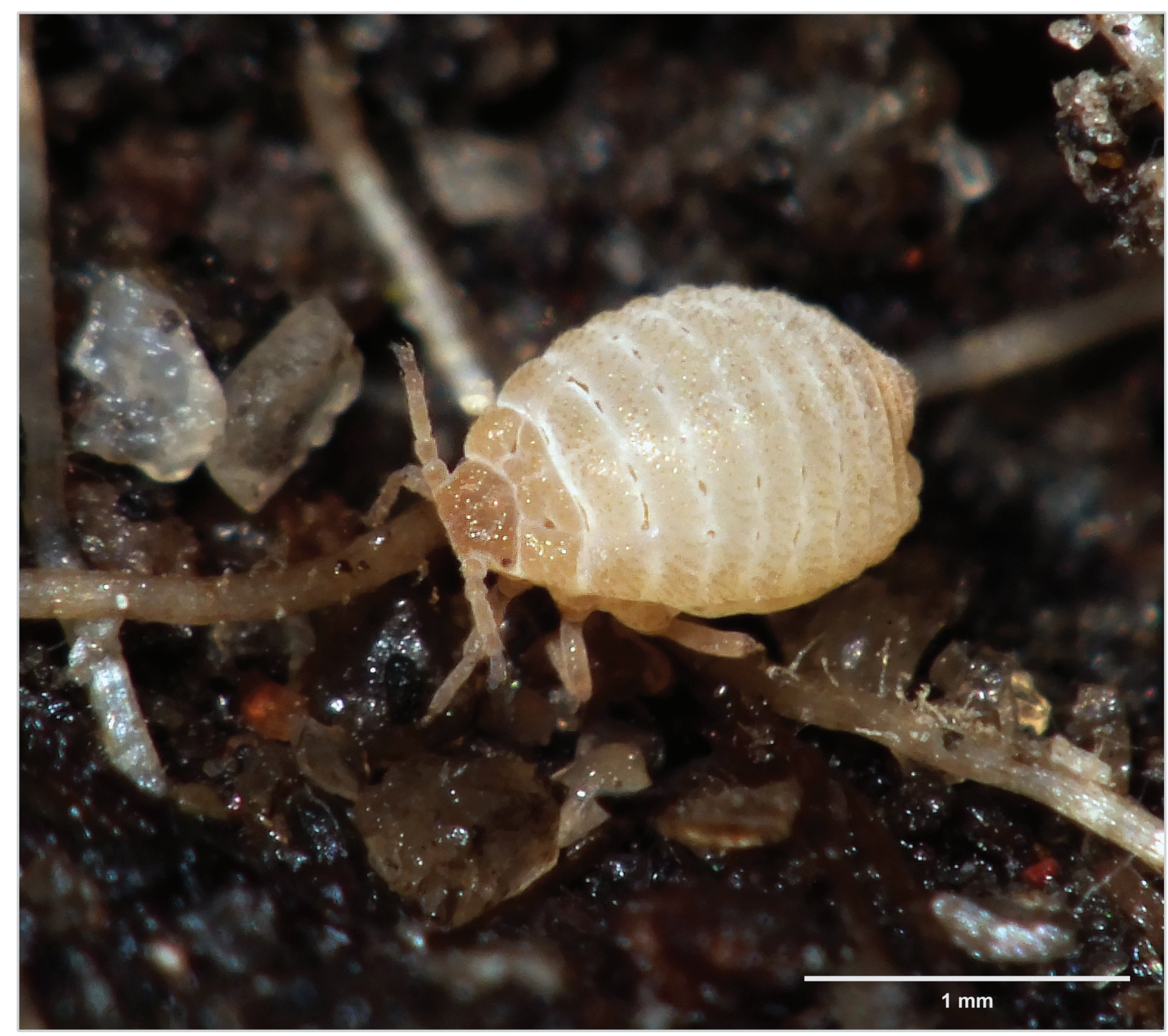

Fig. 17. Geoica utricularia (Passerini, 1856). Apt. on grass root. 
galls on pistachio Pistacia (Anacardiaceae) and grasses (Poaceae). In Northern Europe anholocyclic on grass roots (Poaceae). I have observed a few individuals feeding on Polytrichum commune* (Polytrichaceae) in a Lasius flavus nest mound during extreme drought when the grasses had dried out. Always accompanied by Lasius ants.

\section{Distribution}

D F S.

\section{Recorded moss host}

Polytrichaceae Polytrichum commune (occasionally).

ABD. Colour whitish, cream, pale green or pale yellow; dorsal hairs pointed

ABDA. Body robustly built, global or ovoid, $0.5-1.5 \mathrm{~mm}$. Tarsi with segments fused (in practice 1-segmented); antennae 4-5-segmented. Legs, antennae and rostrum short and stout

Genus Melaphis Walsh, 1867

Melaphis rhois (Fitch, 1866)

\section{Diagnosis}

Diagnosis based on Pike et al. (2012). Resembling Pachypappella lactea but marginal wax gland plates on segments 1-6 in six longitudinal rows (in P. lactea in four rows on segments 3-6). Legs, antennae and rostrum short and stout; tarsi 1-segmented, ant. normally 4-segmented. RIV+V without pale subapical zone. Dioecious, alternating between leaf galls on Rhus glabra and R. hirta (syn. typhina, Anacardiaceae) and mosses (Bryophyta). In northern Europe anholocyclic on mosses. For detailed descriptions, see Pike et al. (2012).

\section{Recorded secondary hosts}

Brachytheciaceae: Eurhynchium striatum; Hypnaceae: Hyocomium armoricum, Hypnum; Polytrichaceae: Polytrichum commune; Sphagnaceae: Sphagnum.

\section{Distribution}

S (if correctly identified: Heie's (1980) fig. 243 based on material from Sweden is probably Pachypappella lactea).

Tribe Pemphigini

Genus Pachypappella Baker, 1920

Pachypappella lactea (Tullgren, 1909)

Fig. 18, 19D

\section{Diagnosis}

Apterae ovoid, robustly built, $0.6-1 \mathrm{~mm}$, whitish, with a thin wax-dusting and exuding wax tufts from spinal and pleural wax gland plates on abdominal segments 3-6 (4 longitudinal rows of plates); marginal wax gland plates absent. Legs, antennae and rostrum short and stout. Antennae 4-5-segmented. Hind femur not distinctly thickened. RIV+V with a rather narrow and indistinct pale subapical zone. Tarsal segments fused (the segment border depicted in fig. 66b by Blackman \& Eastop $(1994,2014)$ looks anomalous, and may be an artefact).

Dioecious, alternating between leaf galls on aspen Populus tremula (Salicaceae) and Norway spruce Picea abies (Pinaceae), where the aphids live on thin roots within and above the mor layer (a compacted 
ALBRECHT A.C., Identification guide to Nordic aphids

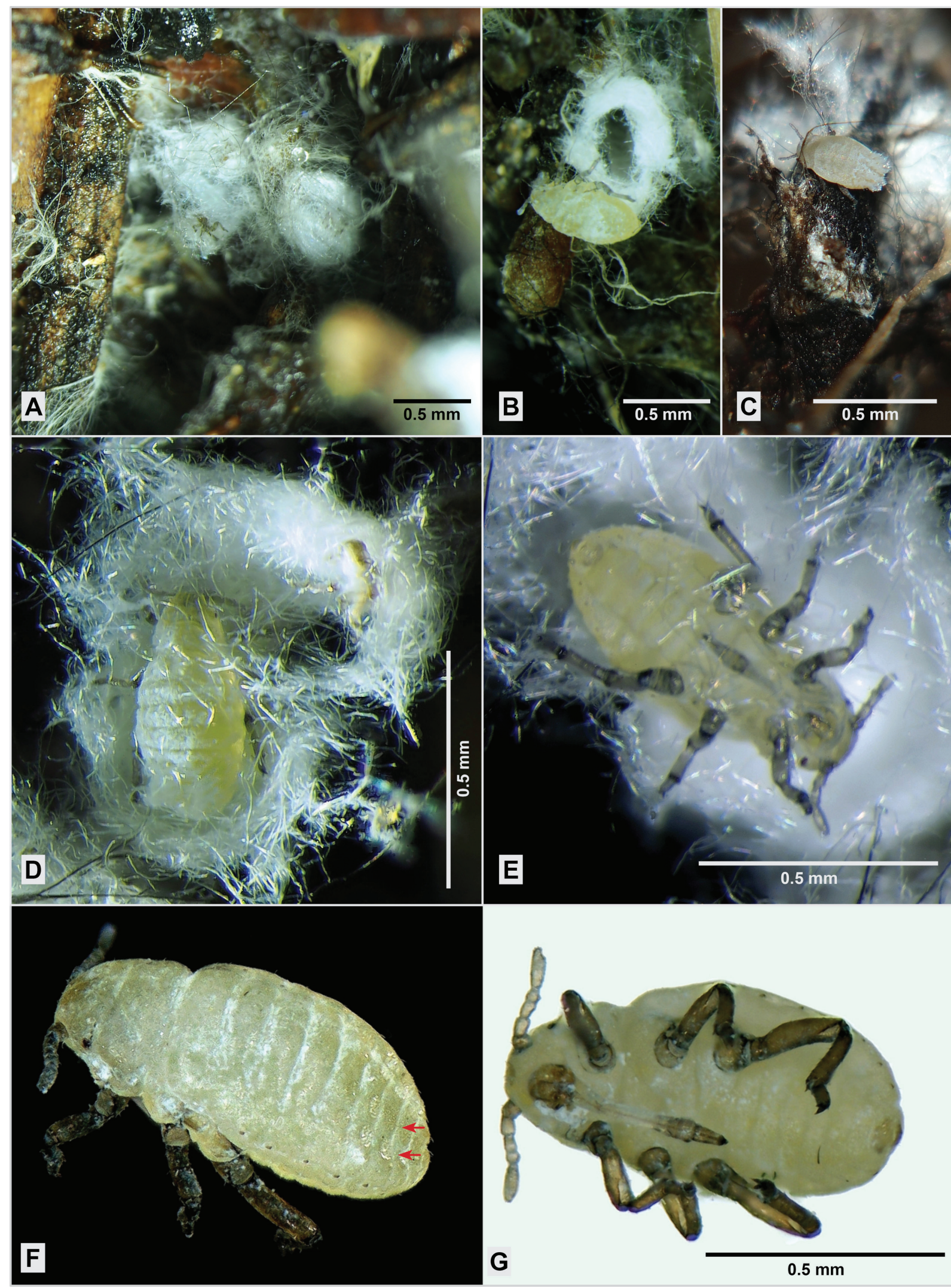

Fig. 18. Pachypappella lactea (Tullgren, 1909). A-E. Apt. and wax cells on terminal Picea abies roots. F-G. Apt. from Hylocomium splendens sample. Two wax gland plates in F indicated by arrows. 
humus layer beneath the moss layer), among moss or litter. The apterae reside in nests of dense wax wool, 1.5-2 mm across, usually one aphid in each. The nests often occur in small groups, often within the looser, wider and less distinctly delimited wax exudate of Prociphilus xylostei (deGeer, 1773) and Pachypappa species. P. lactea has a continuous anholocyclic population on spruce roots. Not associated with ants. Danielsson (1990a, 1990b) gives keys and descriptions of the root-feeding generations of Pachypappella, Gootiella and Pachypappa. See also Carter \& Danielsson (1991).

\section{Distribution}

F N S.

Genus Gootiella Tullgren, 1925

Gootiella tremulae Tullgren, 1925

Fig. 19C

\section{Diagnosis}

Diagnosis based on Danielsson (1990b). Apterae globular to ovoid, 0.9-1.5 mm, grey, covered in white wax. In many respects resembling Pachypappella lactea, but readily distinguished by the remarkably thickened hind femora. Antennae 5-segmented. Dioecious, alternating between Populus tremula (Salicaceae) and juniper Juniperus communis (Cupressaceae), where the aphids live in wax nests similar to those of P. lactea, and commonly overwinter there (Danielsson 1990b).

\section{Distribution}

D F N S.

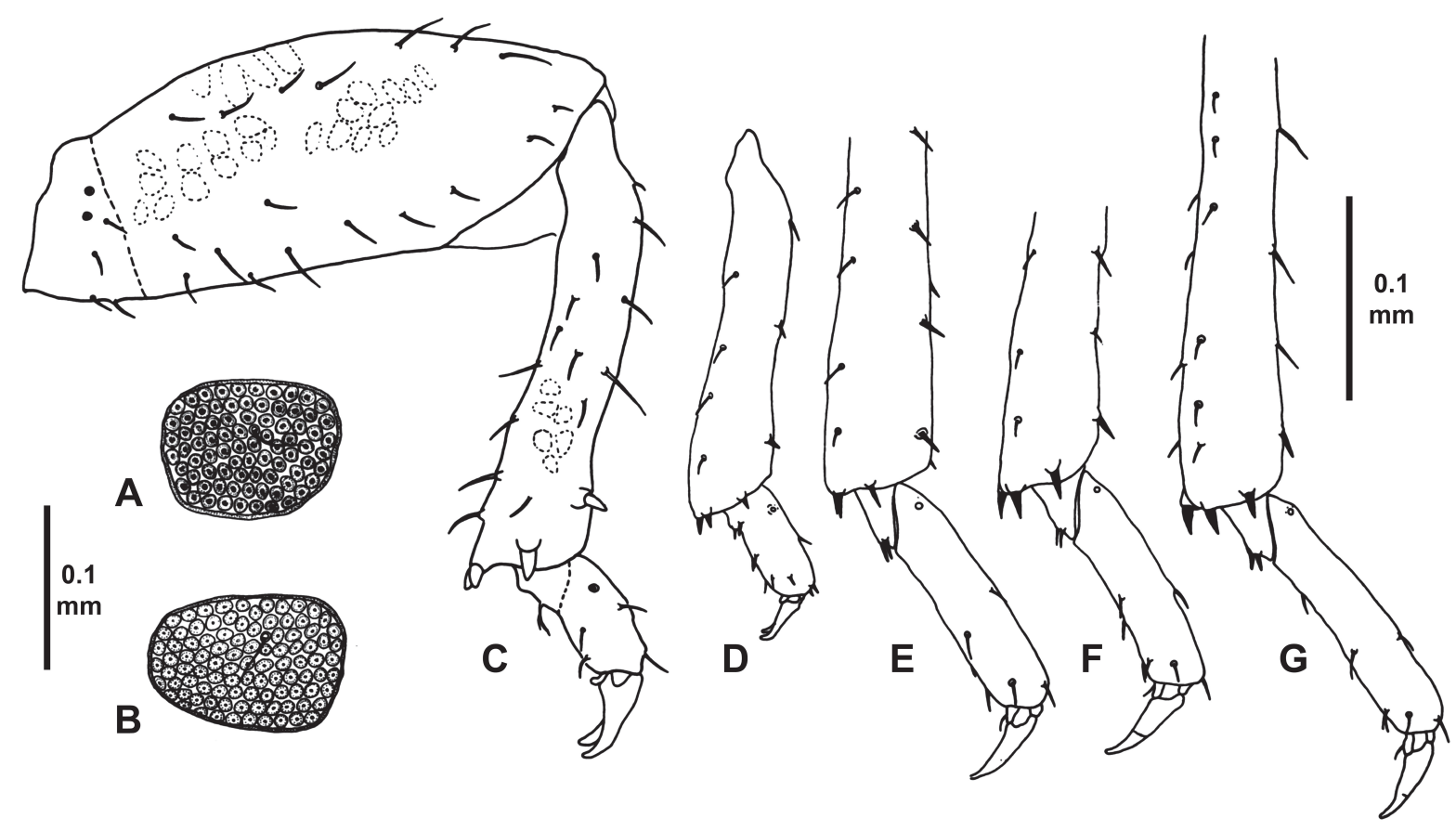

Fig. 19. Gootiella, Pachypappa and Pachypappella. Apt. alienicolae (born on secondary host). A-B. Spinal wax gland on abd. terg. 6 of Pachypappa populi (Linnaeus, 1758) (A) and P. vesicalis Koch, 1856 (B). C. Hind leg of Gootiella tremulae Tullgren, 1925. D-G. Hind tibia and tarsus of Pachypapella lactea (Tullgren, 1909) (D), Pachypappa tremulae Tullgren, 1925 (E), P. populi (Linnaeus, 1758) (F) and $P$. vesicalis Koch, 1856 (G). A-B and D-G after Carter \& Danielsson 1991, C after Danielsson 1990b. All modified. 
ABDB. Body elongate, 1-2.5 mm. Legs, antennae and rostrum more slender; tarsi 1-2-segmented; antennae 5-6-segmented

ABDBA. RIV+V with a broad, distinct, pale subapical zone. Head without wax gland plates

Genus Pachypappa Koch, 1856

Pachypappa populi (Linnaeus, 1758)

Fig. 19 A, F; 20

\section{Diagnosis}

Apterae 1-2 mm, pale yellowish with wax tufts posteriorly. Cells in abdominal wax gland plates with a small central spot (Fig. 19A). Segments 1 and 2 of tarsi less distinctly separated than in P. tremulae (Linnaeus, 1761) and $P$. vesicalis Koch, 1856. Legs longer, hind femur more than $4 \times$ its maximum width. Antennae usually 6-segmented, PT finger-like. Spines at apices of tibiae weak, not much stronger than the hairs on first tarsal segment. Hind tibia on dorsal side bearing 2-5 spine-like hairs with short, blunt apices. Dioecious. Alternating between Populus tremula (Salicaceae) and Picea abies roots (Pinaceae), where wax-covered colonies are formed. Anholocyclic hibernation occurs.

\section{Distribution}

F N S. See also Carter \& Danielsson (1991).

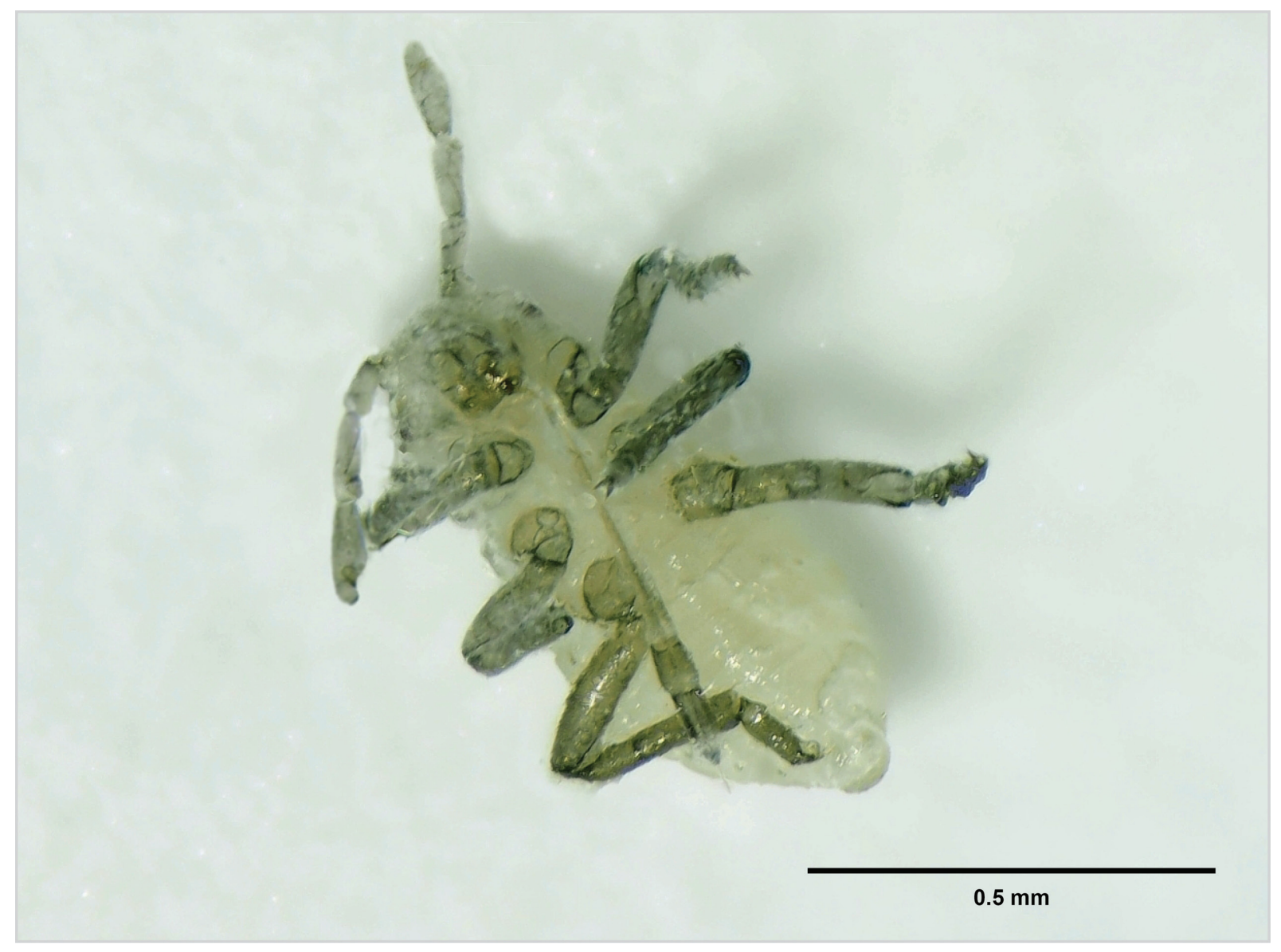

Fig. 20. Pachypappa populi (Linnaeus, 1758). Apt. from mycorrhizal Picea abies root in the moor layer of a shady spruce forest. 

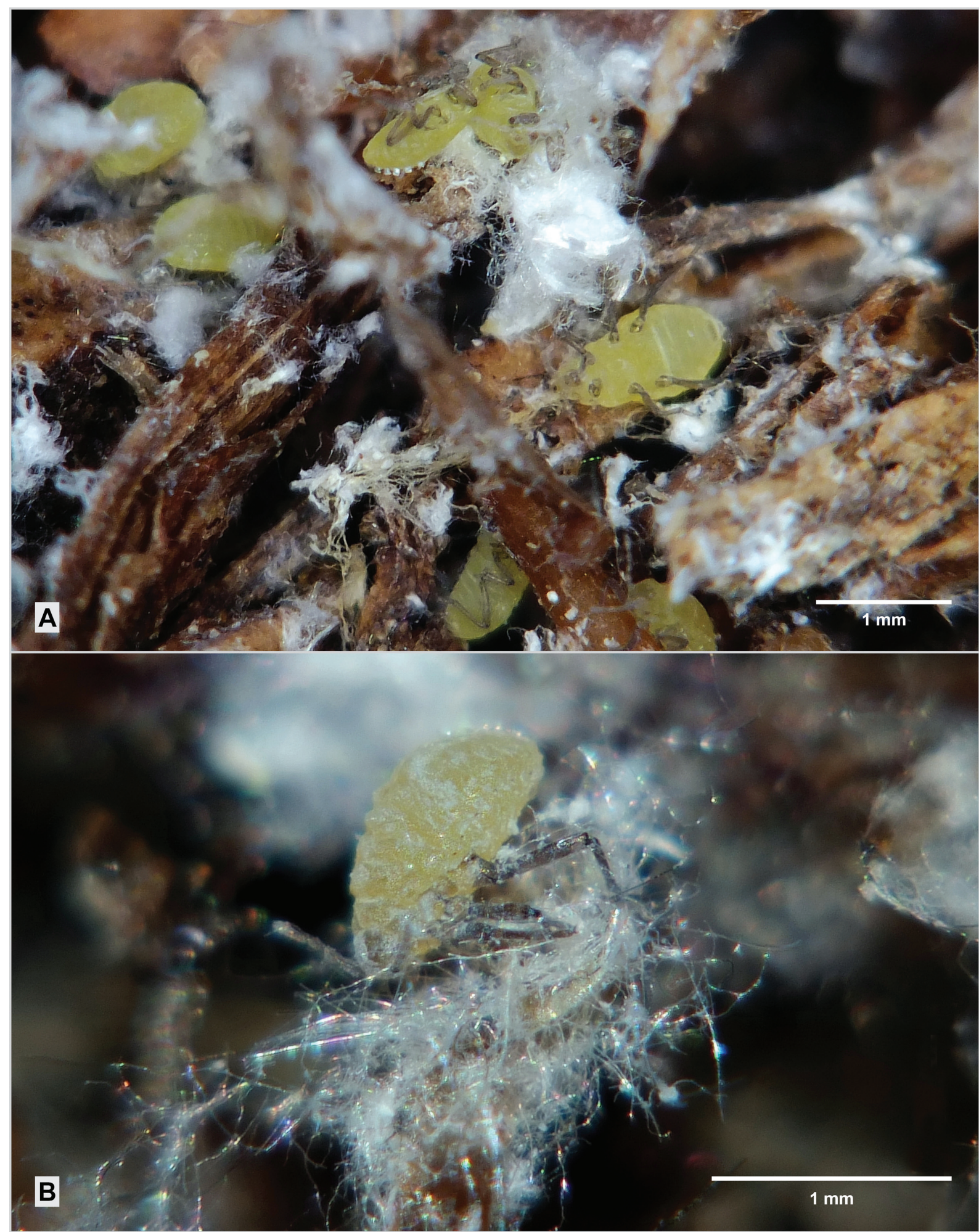

Fig. 21. Prociphilus xylostei (deGeer, 1773). A-B. Apt. on mycorrhizal Picea abies roots under Pleurozium schreberi. 
ALBRECHT A.C., Identification guide to Nordic aphids

\section{Pachypappa tremulae (Linnaeus, 1761)}

Fig. 19E

\section{Diagnosis}

Apterae 1-2 mm. Resembling P. populi. Cells in abdominal wax gland plates with a larger central spot (as in Fig. 19B). Segments 1 and 2 of all tarsi distinctly separated from each other. Spines at apices of tibiae very robust, much stronger than hairs on first tarsal segment. Dorsal hairs on hind tibia with fairly short and blunt apices. Life cycle as in the previous species. Anholocyclic hibernation on roots of spruce Picea is common.

\section{Distribution}

D F N S. See also Carter \& Danielsson (1991).

\section{Pachypappa vesicalis Koch, 1856}

Fig. 19B, G

\section{Diagnosis}

Diagnosis based on Carter \& Danielsson (1991). Resembling P. populi. Antenna usually 5-segmented, PT extremely short. Cells in abdominal wax gland plates with a larger central spot (Fig. 19B). Spines at apices of tibiae very robust, much stronger than the hairs on first tarsal segment. Dorsal hairs on hind tibia with long, pointed apices. Dioecious. Alternates between white poplar Populus alba (Salicaceae) and Picea roots (Pinaceae) where the aphids live in wax nests similar to those of Pachypapella lactea (Carter \& Danielsson 1991).

\section{Distribution}

F S.

ABDBB. Pale subapical zone on RIV+V narrow, indistinct or absent. Wax glands may be present on head

Genus Prociphilus Tullgren, 1925

Prociphilus xylostei (deGeer, 1773)

Fig. 21

\section{Diagnosis}

Apterae 1.2-2 mm, pale green with large wax gland plates (and wax tufts unless worn off) on head and abdomen. RIV+V $=0.2 \times$ HT2, without pale subapical zone. Legs and antennae slender. Dioecious. Alternating between honeysuckle Lonicera (Caprifoliaceae) and thin, mycorrhizal Picea abies roots (Pinaceae), where the colonies are coated with wax wool and where the aphids may hibernate. P.xylostei apparently has a continuous anholocyclic population on spruce roots. Common in moss samples from spruce forests.

\section{Distribution}

D F N S. 


\section{Prociphilus pini (Burmeister, 1835)}

Fig. 22

\section{Diagnosis}

Apterae $1.2-2 \mathrm{~mm}$. As P. xylostei but cream or pale pinkish rather than greenish or yellowish. RIV+V as long as HT2, with narrow and indistinct subapical zone. Dioecious. Alternating between Crataegus

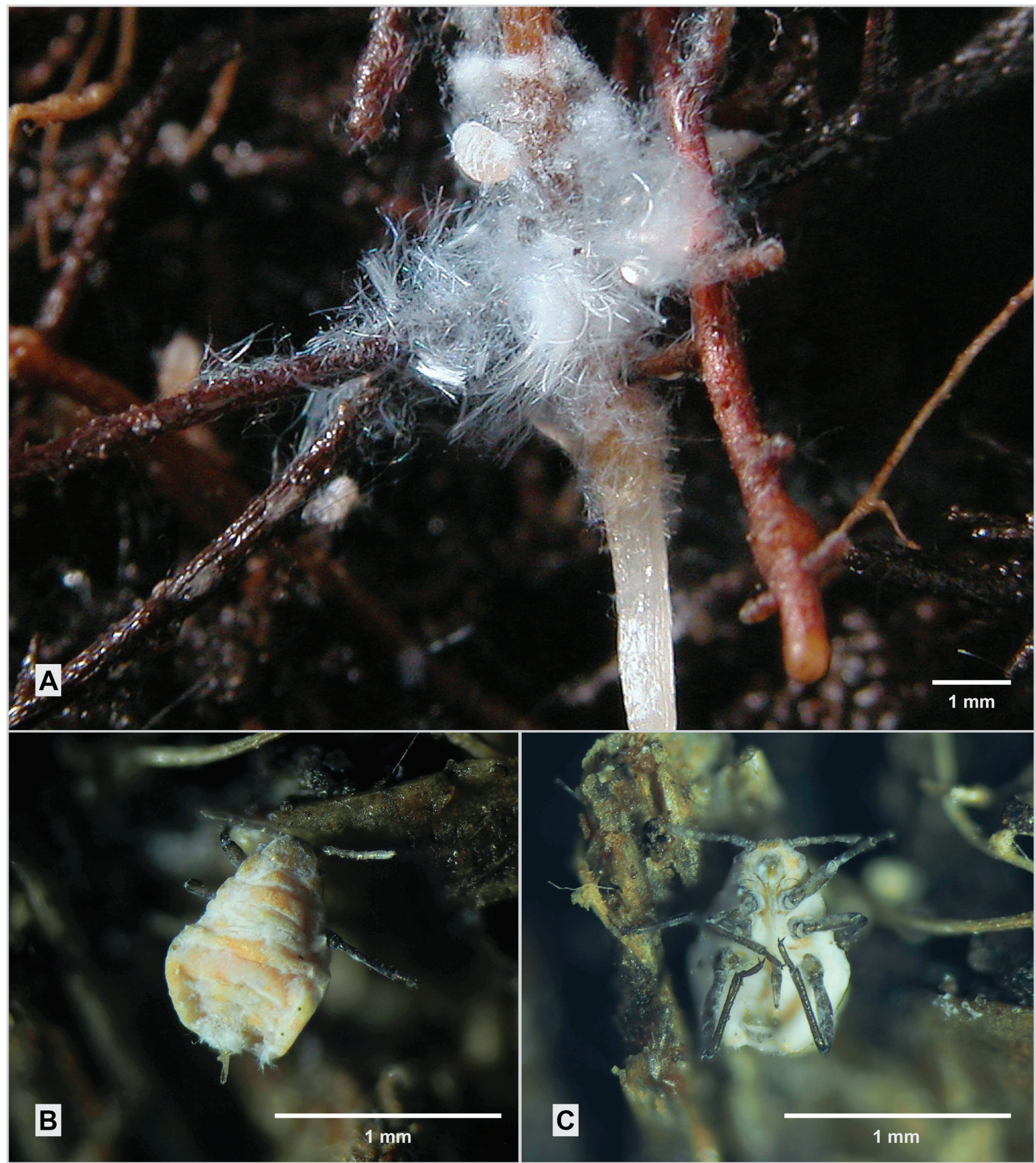

Fig. 22. Prociphilus pini (Burmeister, 1835). A. Colony on thin Pinus sylvestris root in the moor layer of a pine forest on rock. B-C. Apt. from Polytrichum commune sample. 
(Rosaceae) and thin roots of Pinus (Pinaceae). May be found all the year in moss samples in pine forests, especially on rock.

\section{Distribution}

D F N S.

Prociphilus bumeliae (Schrank, 1801)

\section{Diagnosis}

Diagnosis based on Heie (2004). Apterae about $2.9 \mathrm{~mm}$, wax-covered. Two pairs of wax gland plates on head. Posterior plates on head better developed than anterior ones. A narrow pale subapical zone on RIV + V distinct. Dioecious, alternating between ash Fraxinus excelsior (sometimes other Oleaceae) and fir Abies (Pinaceae), where it feeds in wax-covered colonies on the roots.

\section{Distribution}

D F S.

Prociphilus fraxini (Fabricius, 1777)

\section{Diagnosis}

Diagnosis based on Heie (2004). Apterae 1.8-2.7 mm, pale, wax-covered. Very similar to P. bumeliae, but the posterior wax gland plates on head weakly developed, sometimes absent. Dioecious, alternating between Fraxinus excelsior (Oleaceae) and roots of Abies (Pinaceae), where wax-covered colonies are formed.

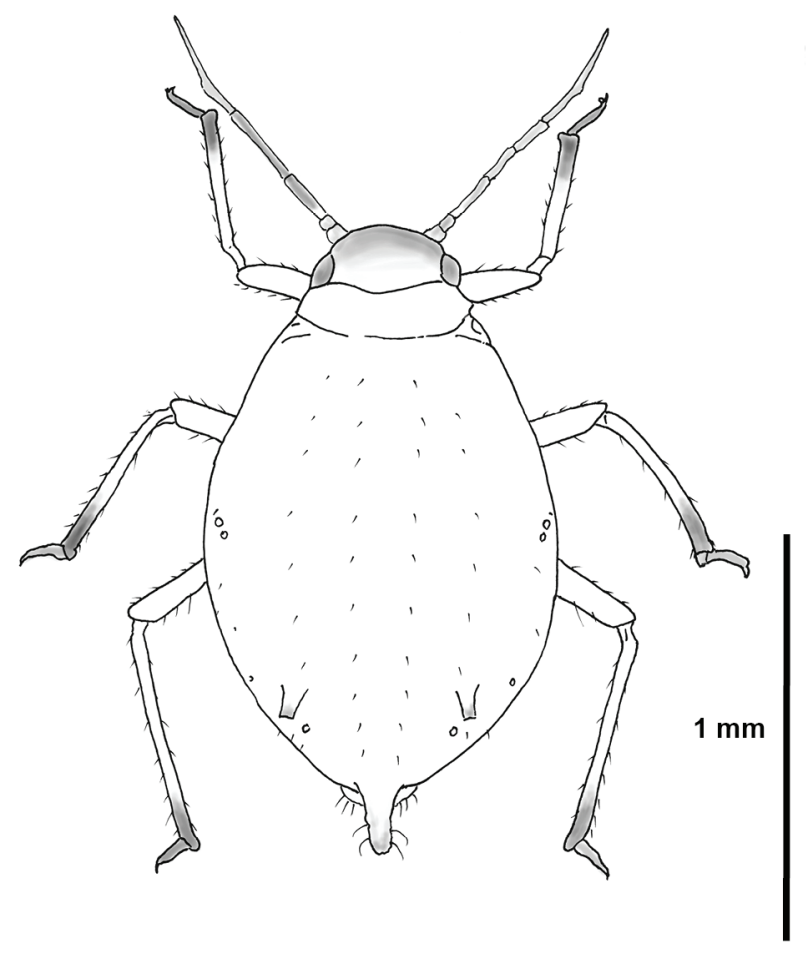

Fig. 23. Aphis equiseticola Ossiannilsson, 1964. Aptera (redrawn after Heie 1986). 


\section{Distribution}

D N S.

Key B. Aphids on horsetails (Equisetophyta)

\section{Synopsis}

BA. Siphunculi present, half as long as cauda or longer............................. p. 30

BAA. Lateral frontal tubercles hardly developed; antennae shorter than body........ p. 30

BAB. Lateral frontal tubercles well developed; antennae usually longer than body

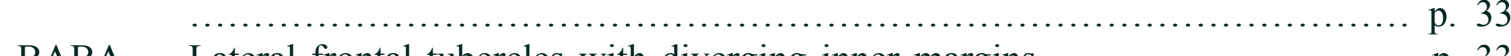

BABA. Lateral frontal tubercles with diverging inner margins....................... p. 33

BABB. Lateral frontal tubercles with parallel or converging inner margins............. p. 35

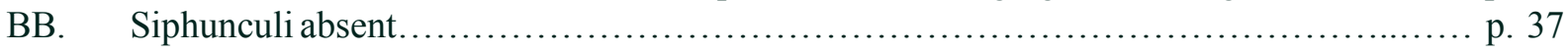

BA. Siphunculi present, half as long as cauda or longer

BAA. Lateral frontal tubercles hardly developed; antennae shorter than body

Subfamily Aphidinae Latreille, 1802

Tribe Aphidini Latreille, 1802

Genus Aphis Linnaeus, 1758

Aphis equiseticola Ossiannilsson, 1964

Fig. 23

\section{Diagnosis}

Diagnosis based on Heie (1986). Aptera 1.4-2.0 mm, light or dark green without markings. Head, antennae, tarsi and tips of tibiae rather dark. Antennae about half as long as body. Siphunculi shorter than cauda, dusky or pale, with dark apices. Monoecious.

\section{Recorded hosts}

Equisetum pratense, E. sylvaticum.

\section{Distribution}

S.

Aphis gossypii Glover, 1877

\section{Diagnosis}

Aptera 0.8-1.7 mm. Pale green to blackish green; siphunculi black. Small, pale yellow specimens occur in in crowded colonies or hot conditions. In cold temperate regions mostly in glasshouses. Dioecious with several unrelated plants as primary hosts, in Europe, however, mostly anholocyclic. Very similar to A. beccabungae Koch, 1855 (Fig. 24) and other species of the A. frangulae group. See Blackman \& Eastop (2014) and Heie (1986) for differences and a more complete account. Dioecious but usually anholocyclic, polyphagous.

\section{Recorded Equisetum host}

E. sylvaticum. 
ALBRECHT A.C., Identification guide to Nordic aphids

\section{Distribution}

D F N S.

\section{Genus Rhopalosiphum Koch, 1854}

Rhopalosiphum padi (Linnaeus, 1758)

Fig. 25

\section{Diagnosis}

Aptera 1-2.4 mm, olive mottled with darker green. Siphuncular area and often also tip of abdomen rust-red. Juveniles paler, matt, with thin wax dusting. Siphunculus almost straight, longer than cauda, with subapical constriction and apical flange. Dioecious, alternating between Prunus and graminoids (Poaceae, Cyperaceae, Juncaceae), rarely on other hosts, exceptionally on Equisetum. Recorded from E. sylvaticum.

\section{Distribution}

D N F Fa I S.

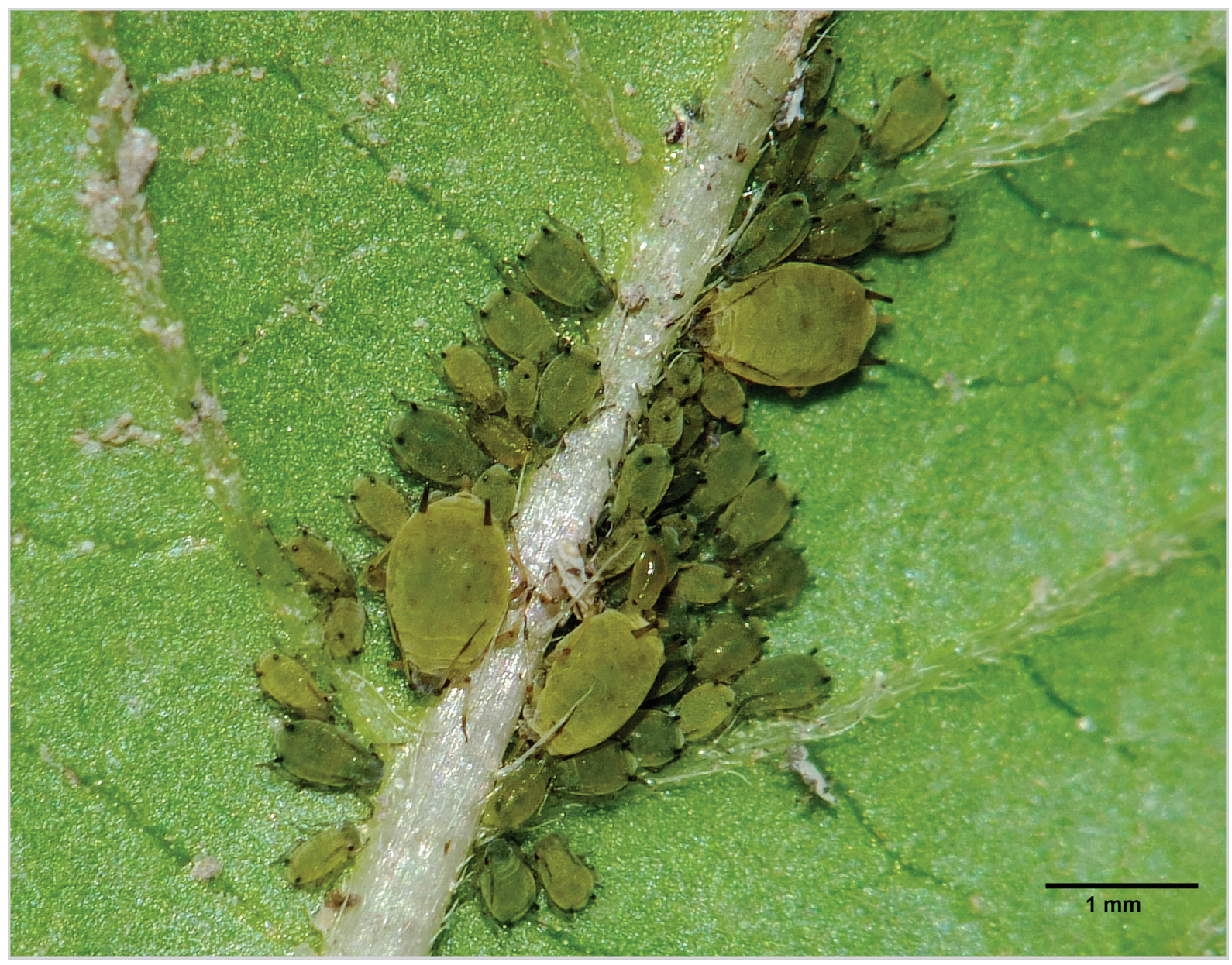

Fig. 24. Aphis beccabungae Koch, 1855. Apt. and juv. on Galeopsis speciosa. A. beccabungae is very similar to A. gossypii Glover, 1877. 


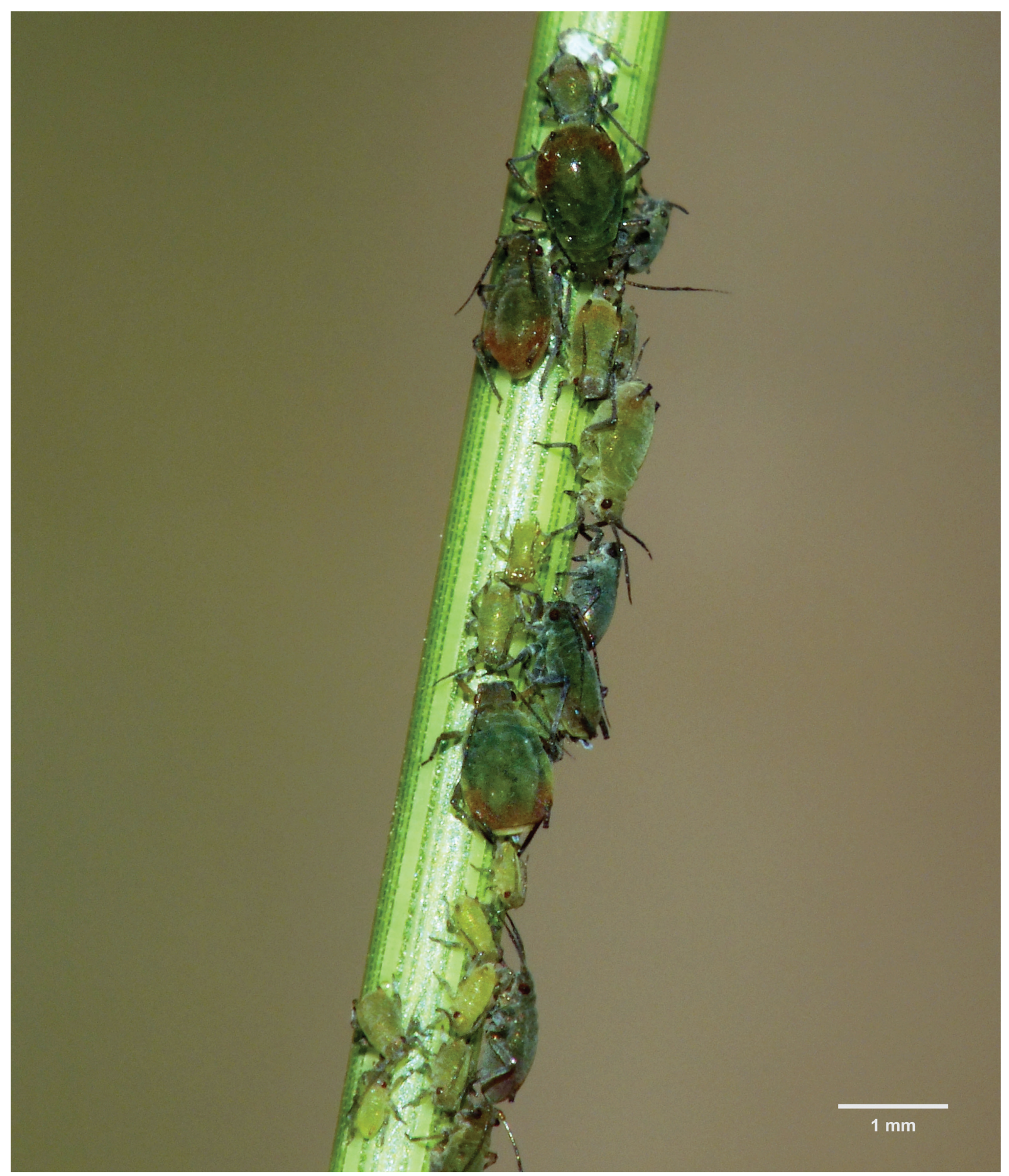

Fig. 25. Rhopalosiphum padi (Linnaeus, 1758), apt. and juv. on Poa pratensis. 
BAB. Lateral frontal tubercles well developed; antennae usually longer than body

BABA. Lateral frontal tubercles with diverging inner margins

Tribe Macrosiphini Wilson, 1910

Genus Macrosiphum Passerini, 1860

Macrosiphum equiseti (Holman, 1961)

Fig. 26

\section{Diagnosis}

Aptera 1.6-3 mm, bright green without markings, body with thin whitish wax dusting on venter (adults) or all over (juveniles). Siphunculi length rarely over $1.35 \times$ cauda length. Holocyclic, monoecious. Damp, shady broad-leaved and spruce forests.

\section{Recorded hosts}

Equisetum arvense, E. pratense, E. sylvaticum*, E. telmateia.

\section{Distribution}

F S.

Genus Sitobion Mordvilko, 1914

Sitobion avenae (Fabricius, 1775)

Fig. 27

\section{Diagnosis}

Aptera $1.2-3.5 \mathrm{~mm}$, green with black muscle sclerites. Legs and antennae partly black. Siphunculi black. Cauda pale. Abdominal dorsum sclerotised, shiny, all green, all black, or green with grey or black transverse bars. Juveniles matt, apt. juv. green, al. juv. brown. Holocyclic, monoecious on grasses (Poaceae), exceptionally on Equisetum sylvaticum. Not ant-attended.

\section{Distribution}

D F N S.

Sitobion fragariae (Walker, 1848)

\section{Diagnosis}

Similar to $S$. avenae, but generally paler, usually without blackened patches on dorsum. Siphunculi longer, more than $1.7 \times$ cauda. Holocyclic, dioecious, alternating between Rubus subgenus Rubus and grasses (Poaceae). Exceptionally on Equisetum, recorded from E. sylvaticum.

\section{Distribution}

D F Fa N S. 

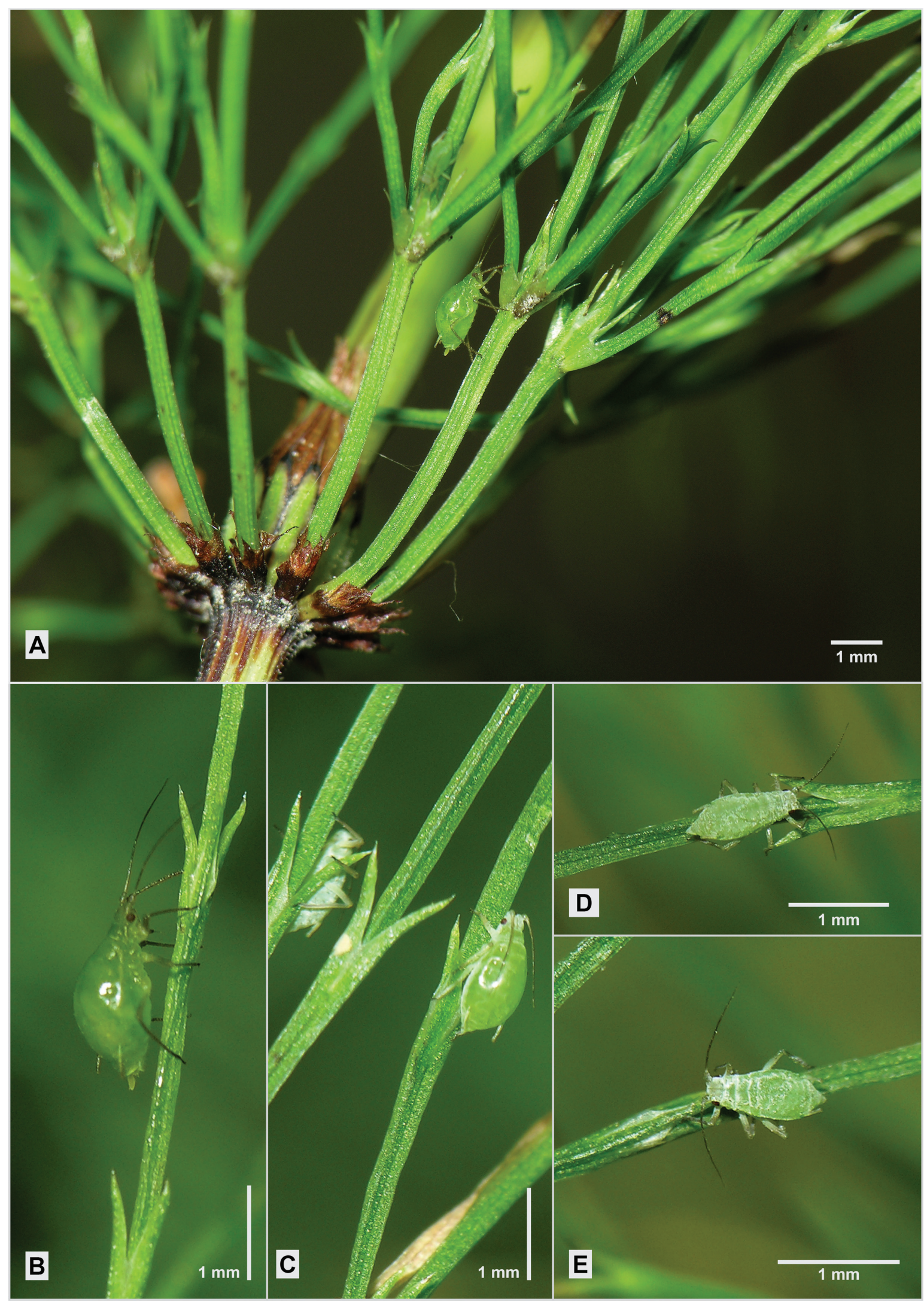

Fig. 26. Macrosiphum equiseti (Holman, 1961) on Equisetum sylvaticum. A-C. Apterae. D-E. Juveniles. 
ALBRECHT A.C., Identification guide to Nordic aphids

BABB. Lateral frontal tubercles with parallel or converging inner margins

Genus Aulacorthum Mordvilko, 1914

Aulacorthum solani (Kaltenbach, 1843)

Fig. 28

\section{Diagnosis}

Aptera 1.2-2.6 mm, green with dark green spots in front of siphunculi. At most with very slight wax dusting ventrally. Occupying a wide range of habitats, also a common indoor pest. Holocyclic or anholocyclic, monoecious, polyphagous. Not ant-attended.

\section{Recorded Pteridophyta hosts}

Equisetaceae: Equisetum fluviatile*; Aspleniaceae: Asplenium trichomanes; Athyriaceae: Athyrium filixfemina*; Polypodiaceae: Polypodium vulgare; Pteridaceae: Adiantum capillus-veneris.

\section{Distribution}

D F I N S.

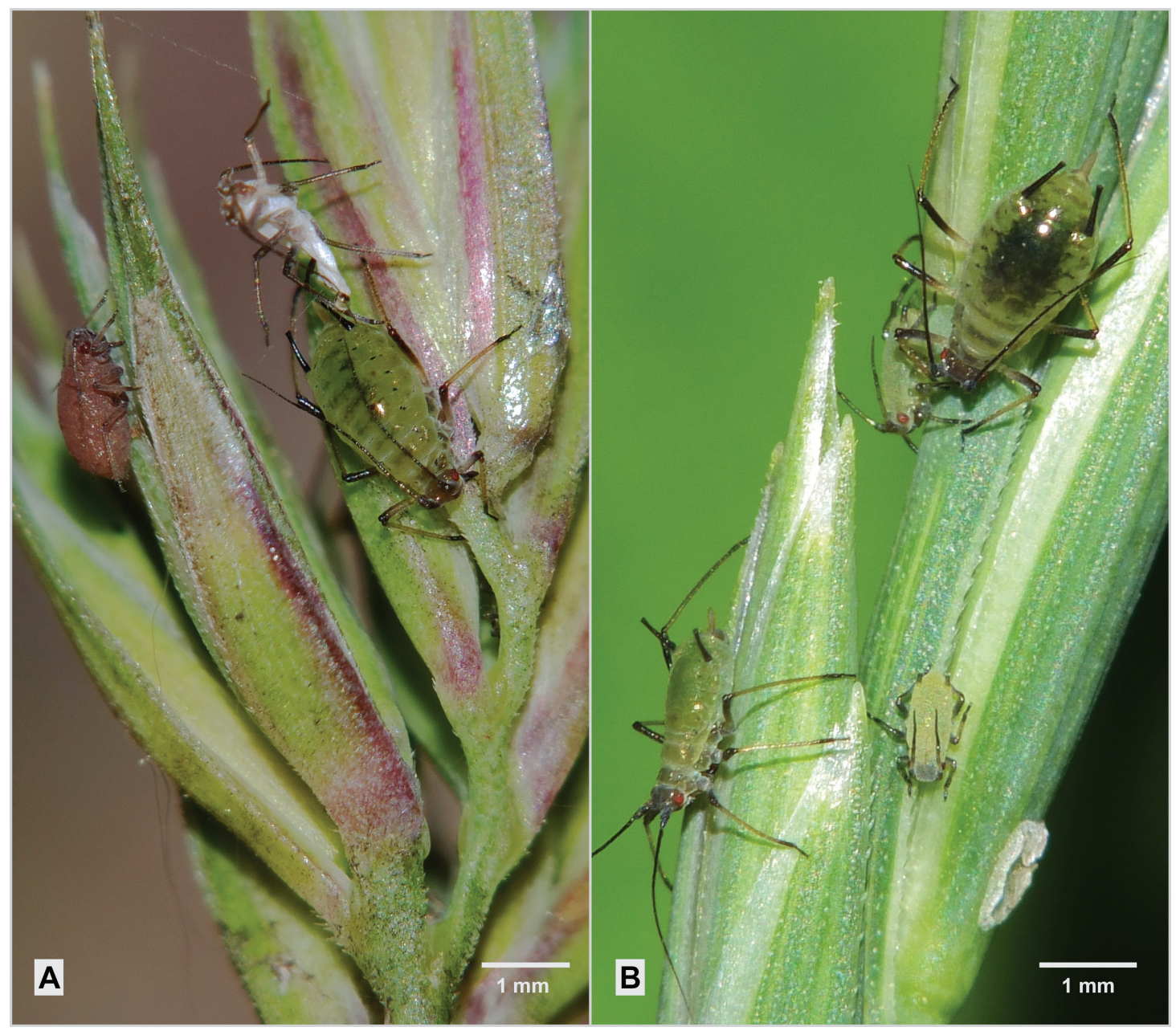

Fig. 27. Sitobion avenae (Fabricius, 1775). Apterae and juveniles on A. Dactylis glomerata and B. Elytrigia repens. 


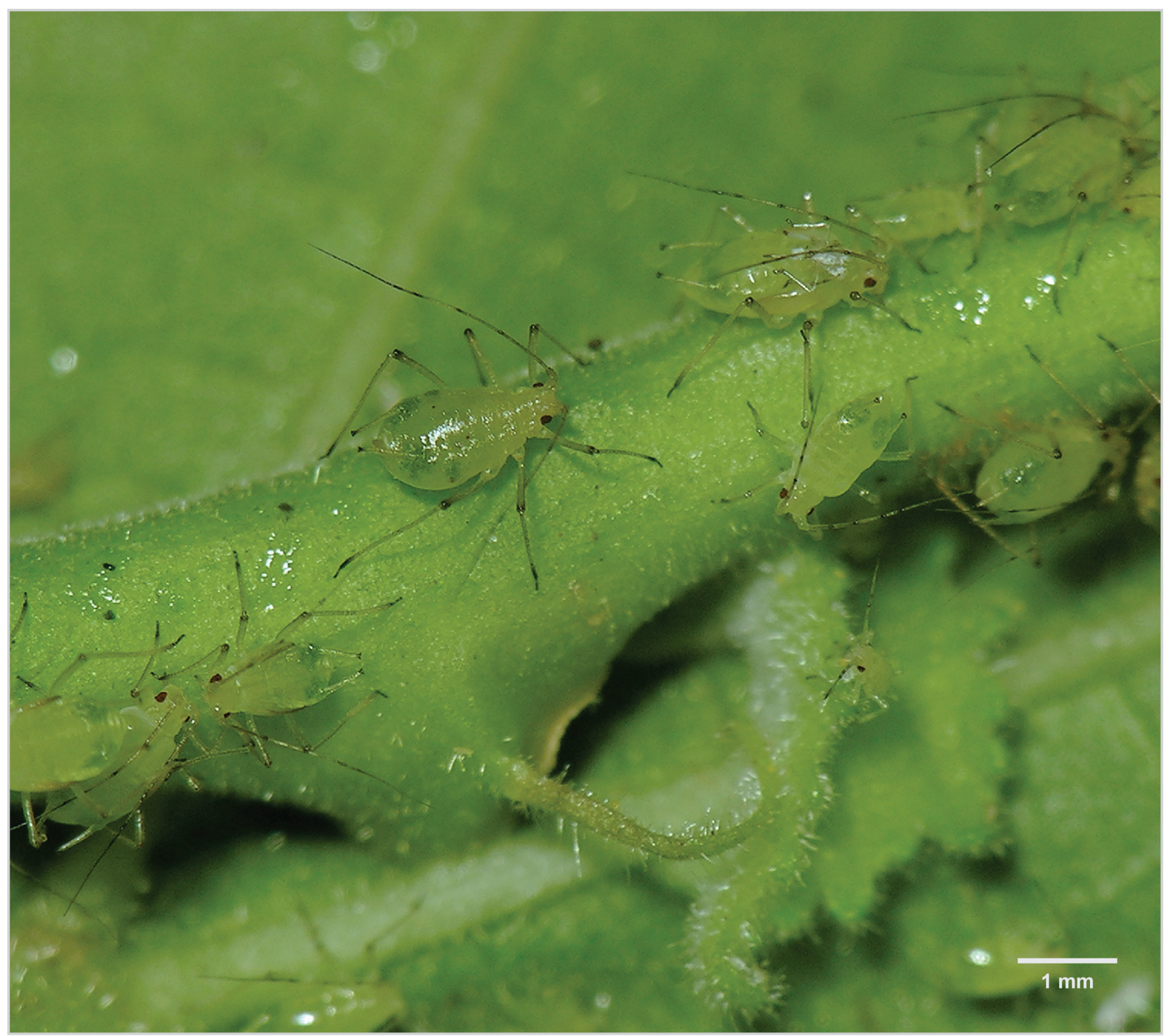

Fig. 28. Aulacorthum solani (Kaltenbach, 1843). Apterae and juveniles on Abutilon sp.

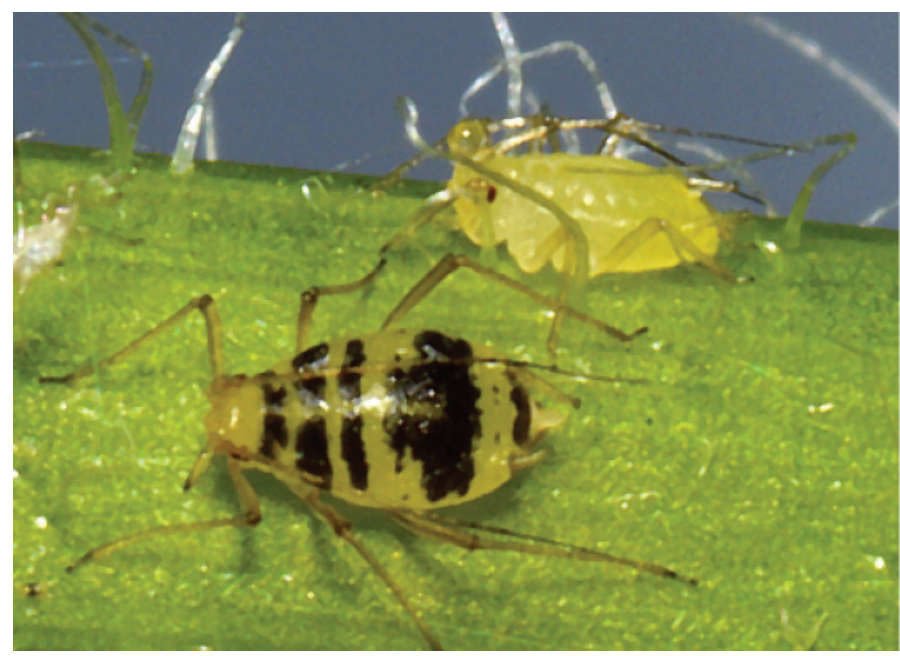

Fig. 29. Neomyzus circumflexus (Buckton, 1876). Aptera. (from Dransfield \& Brightwell 2015, licensed under Creative Commons Attribution 3.0, downloaded 30 Jun. 2015). 
ALBRECHT A.C., Identification guide to Nordic aphids

Genus Neomyzus van der Goot, 1915

Neomyzus circumflexus (Buckton, 1876)

Fig. 29

\section{Diagnosis}

Diagnosis based on Heie (2004). Rather similar to Aulacorthum solani. Whitish, yellow or green; abdomen with brown or black markings, usually including a horseshoe-shaped patch. Monoecious, polyphagous, apparently anholocyclic (sexuales not recorded).

\section{Recorded Pteridophyta hosts}

Equisetaceae: Equisetum arvense*; Aspleniaceae:Asplenium sp.; Dryopteridaceae: Cyrtomium falcatum, Polystichum lonchitis; Nephrolepidaceae: Nephrolepis sp.; Onocleaceae: Matteuccia struthiopteris; Polypodiaceae: Polypodium vulgare; Pteridaceae: Adiantum sp.*; Salviniaceae: Salvinia auriculatia.

\section{Distribution}

D F N S, in Northern Europe mainly indoors.

$$
\begin{gathered}
\text { Genus Myzus Passerini, } 1860 \\
\text { Myzus cerasi (Fabricius, 1775) } \\
\text { Fig. } 30
\end{gathered}
$$

\section{Diagnosis}

Aptera 1-1.5 mm, shining black, almond-shaped. Legs and antennae partly pale. Juveniles brown. Holocyclic, dioecious, alternating between Prunus and herbs of several families, rarely on Equisetum.

\section{Recorded Pteridophyta host}

Equisetum sp.

\section{Distribution}

D F N S.

\section{BB. Siphunculi absent}

Subfamily Eriosomatinae

Tribe Fordini

Genus Paracletus von Heyden, 1837

Paracletus cimiciformis von Heyden, 1837

Fig. 31

\section{Diagnosis}

Aptera 2.2-3.4 mm, broadly oval, flattened, rather shining cream with brown legs and antennae. Dioecious, alternating between leaf galls on Pistacia and roots of grasses and herbs. In N. Europe anholocyclic, normally feeding on grass (Poaceae). In xerothermic habitats. Lives in association with ants, usually Tetramorium caespitum (Linnaeus, 1758).

\section{Distribution}

F S. 


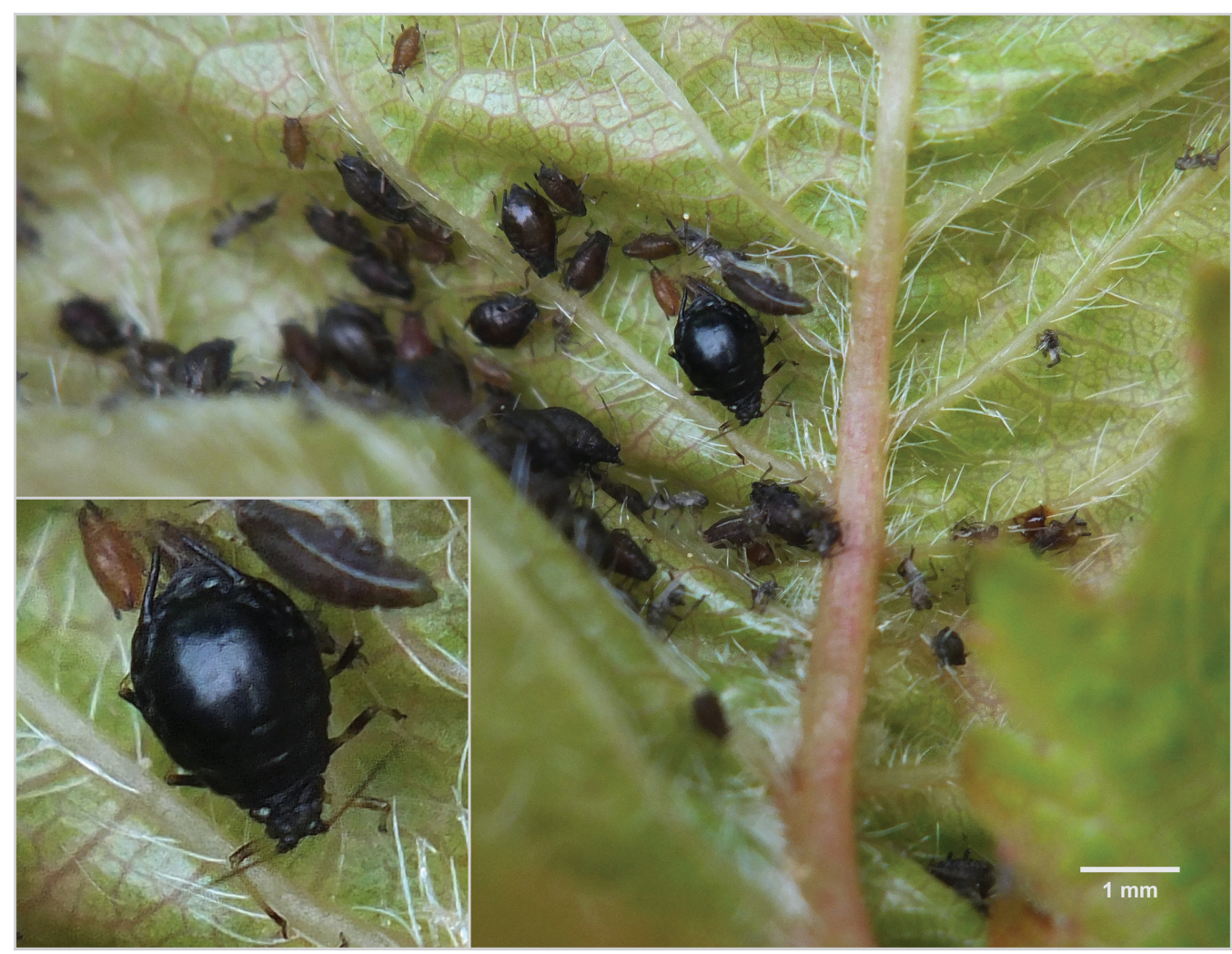

Fig. 30. Myzus cerasi (Fabricius, 1775). Apt. and juv. on Prunus cerasus.

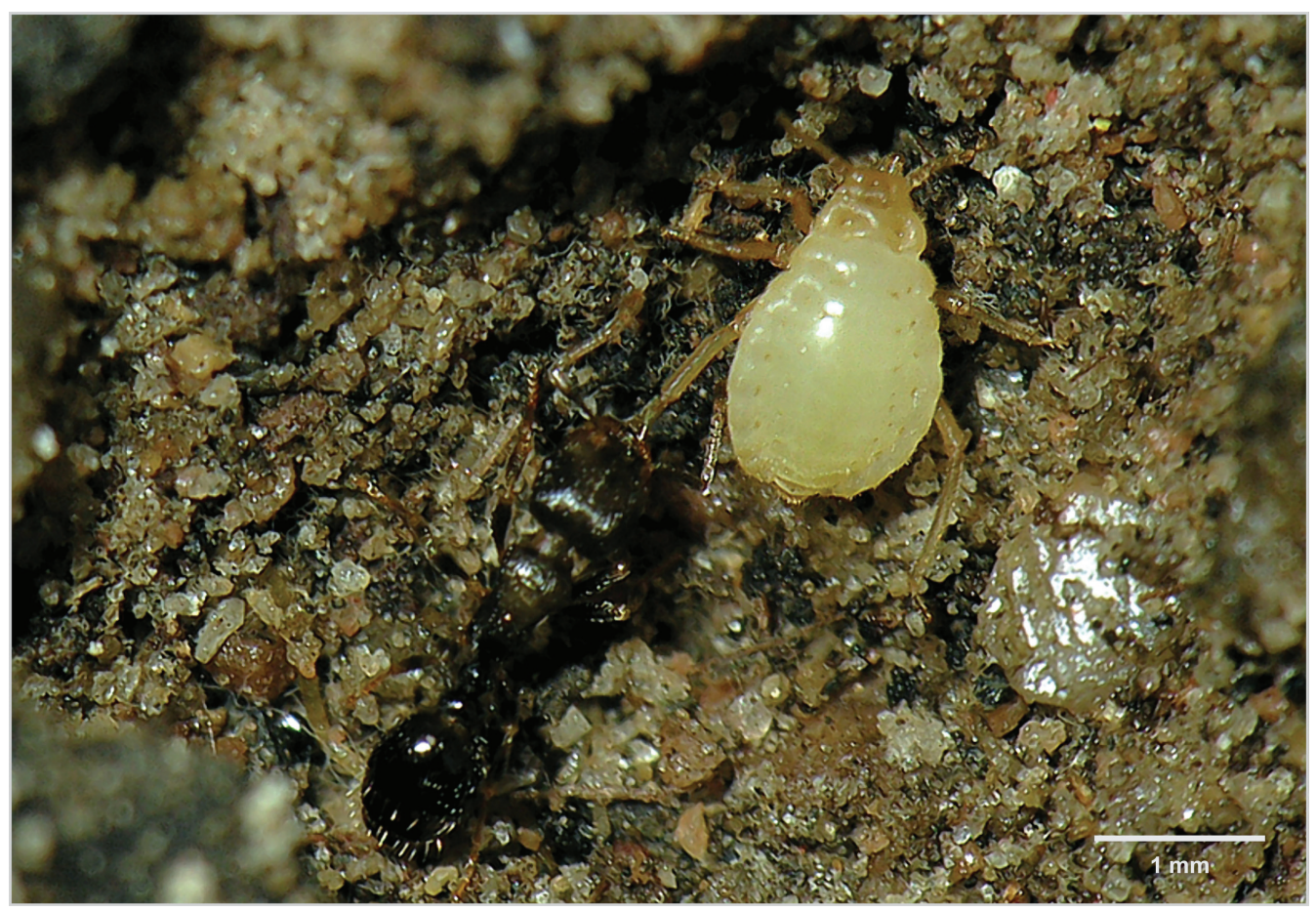

Fig. 31. Paracletus cimiciformis von Heyden, 1837. Aptera in nest of Tetramorium caespitum (Linnaeus, 1758). 


\title{
Recorded Pteridophyta host
}

Equisetaceae: Equisetum arvense.

\section{Key C. Aphids on ferns (Polypodiophyta)}

\section{Synopsis}

CA. Black with pale legs and siphunculi, and pale-ringed antennae....................... p. 39

CB. Green, brown, yellowish or reddish aphids..................................... p. 40

CBA. Lateral frontal tubercles hardly developed; mainly on aquatic plants........... p. 40

CBB. Lateral frontal tubercles with diverging inner margins....................... p. 41

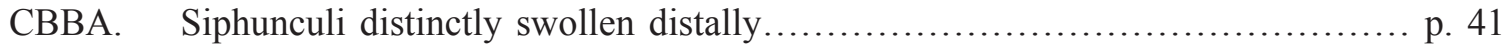

CBBB. Siphunculi at most slightly swollen.................................... p. 41

CBC. Lateral frontal tubercles with parallel or converging inner margins............... p. 43

CA. Black with pale legs and siphunculi, and pale-ringed antennae

\author{
Subfamily Aphidinae Latreille, 1802 \\ Tribe Macrosiphini Wilson, 1910 \\ Genus Idiopterus Davis, 1909
}

Idiopterus nephrelepidis Davis, 1909

(Fig. 32)

\section{Diagnosis}

Diagnosis based on Heie (1994). Aptera 1.2-1.6 mm. Apparently anholocyclic, monoecious, in N Europe in greenhouses.

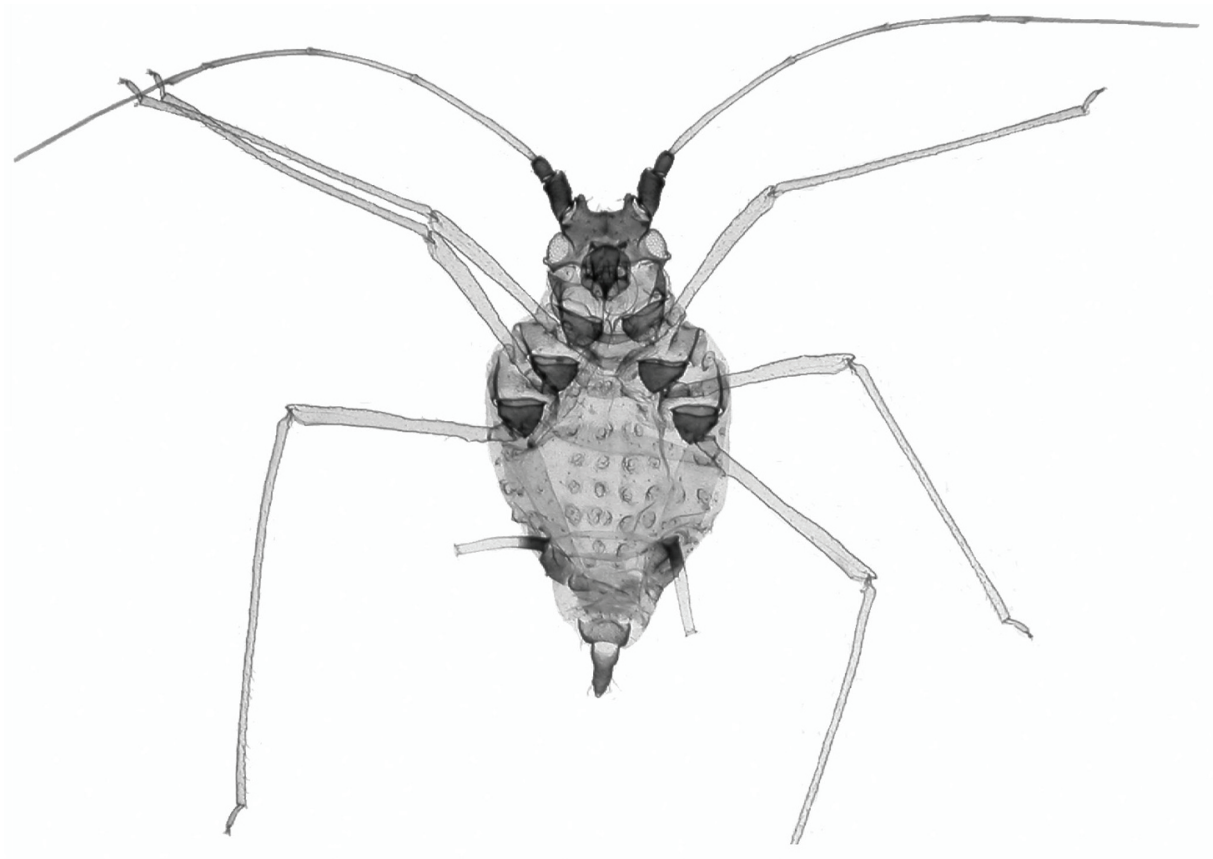

Fig. 32. Idiopterus nephrelepidis Davis, 1909. Aptera (photo Roger Blackman, from Blackman 2010, with license from The Royal Entomological Society). 


\section{Recorded hosts}

Aspleniaceae: Asplenium adiantum-nigrum; A. ruta-muraria, A. scolopendrium; Blechnaceae: Blechnum sp.; Dennstaedtiaceae: Dennstaedtia sp.; Dryopteridaceae: Cyrtomium falcatum; Nephrolepidaceae: Nephrolepis exaltata; Pteridaceae: Adiantum sp., Pteris sp.

\section{Distribution}

D S.

CB. Green, brown, yellowish or reddish aphids

CBA. Lateral frontal tubercles hardly developed; mainly on aquatic plants

Tribe Aphidini Latreille, 1802

Genus Rhopalosiphum Koch, 1854

\section{Rhopalosiphum nymphaeae (Linnaeus, 1761)}

Fig. 33

\section{Diagnosis}

Aptera $1.5-2.5 \mathrm{~mm}$, brown to olive, dusted with greyish wax, particularly on venter and margins, including legs and antennae. Siph. swollen, with a distinct constriction before the apical flange. Holocyclic, dioecious, alternating between Prunus and many unrelated, mostly aquatic or semiaquatic plants. Not ant-attended.

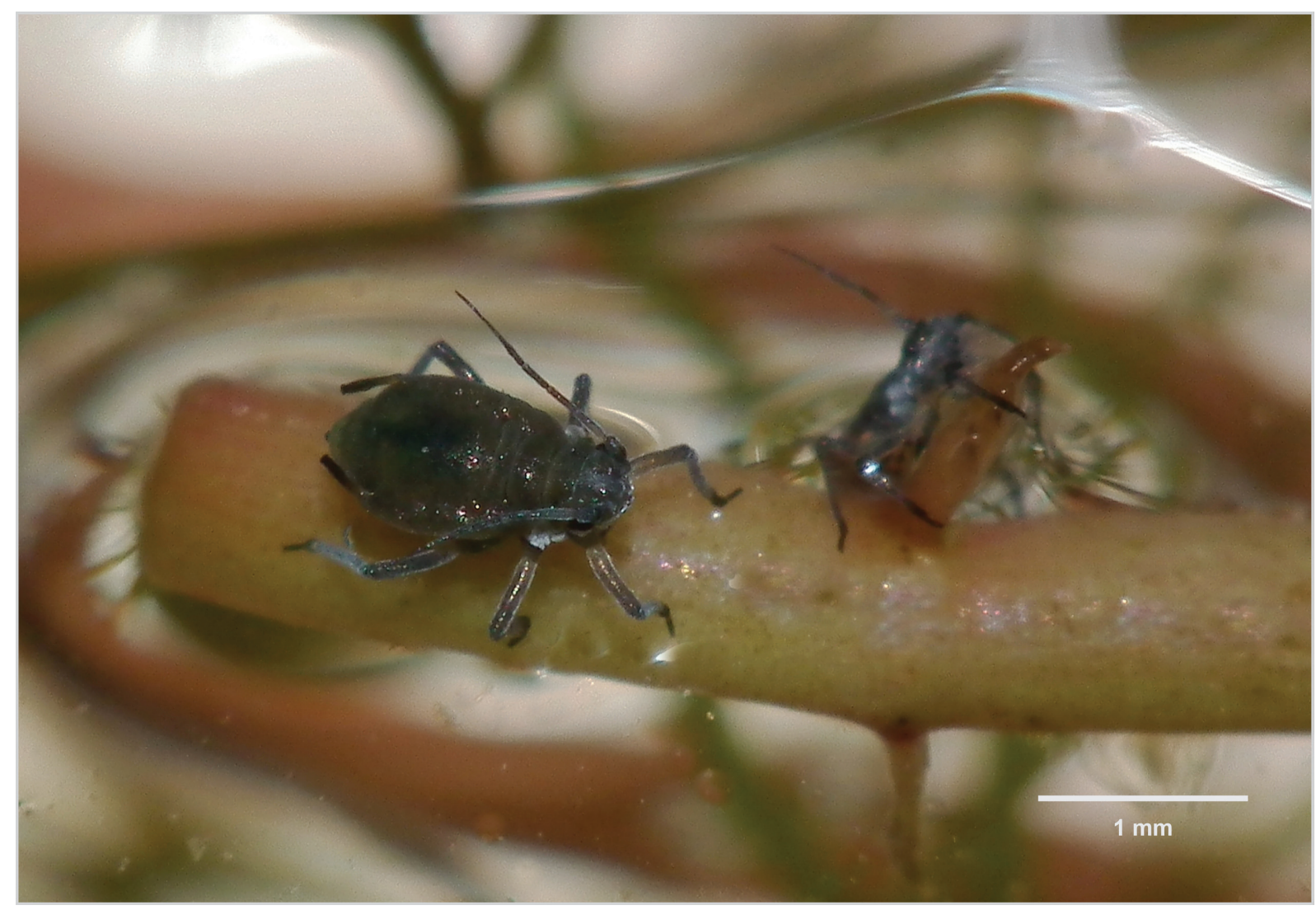

Fig. 33. Rhopalosiphum nymphaeae (Linnaeus, 1761). Aptera on Myripohyllum spicatum. 
ALBRECHT A.C., Identification guide to Nordic aphids

\section{Recorded Pteridophyta hosts}

Marsileaceae: Marsilea quadrifolia, M. strigosa; Salviniaceae: Azolla caroliniana, A. filiculoides, Salvinia auriculatia, S. natans.

\section{Distribution}

D F N S.

CBB. Lateral frontal tubercles with diverging inner margins

CBBA. Siphunculi strongly swollen distally

Tribe Macrosiphini Wilson, 1910

Genus Amphorophora Buckton, 1876

Amphorophora ampullata Buckton, 1876

Fig. 34

\section{Diagnosis}

Aptera 3-5 mm, bright green without markings. Eyes red. Holocyclic, monoecious. Shady places, parks, gardens, mixed and deciduous forests. Not ant-attended.

\section{Recorded hosts}

Aspleniaceae: Asplenium sp.; Athyriaceae: Athyrium filix-femina*; Cystopteridaceae: Cystopteris montana; Gymnocarpium dryopteris; Dennstaedtiaceae: Dennstaedtia sp., Pteridium aquilinum; Dryopteridaceae: Dryopteris carthusiana*, D. dilatata, D. filix-mas, Polystichum sp.; Onocleaceae: Matteuccia struthiopteris*; Thelypteridaceae: Phegopteris connectilis, Thelypteris palustris.

\section{Distribution}

D F N S.

CBBB. Siphunculi at most slightly swollen

Genus Macrosiphum Passerini, 1860

Macrosiphum lapponicum Shaposhnikov, 1964

\section{Diagnosis}

Diagnosis based on Heie (1994). Abdominal dorsum membranous, segmental borders distinct. Apt. about $4 \mathrm{~mm}$, green, yellowish or reddish. Ant. segment 3 with more than 30 rhinaria. Monoecious.

\section{Recorded host}

Athyriaceae: Athyrium distentifolium.

\section{Distribution}

Known from NW Russia only. 


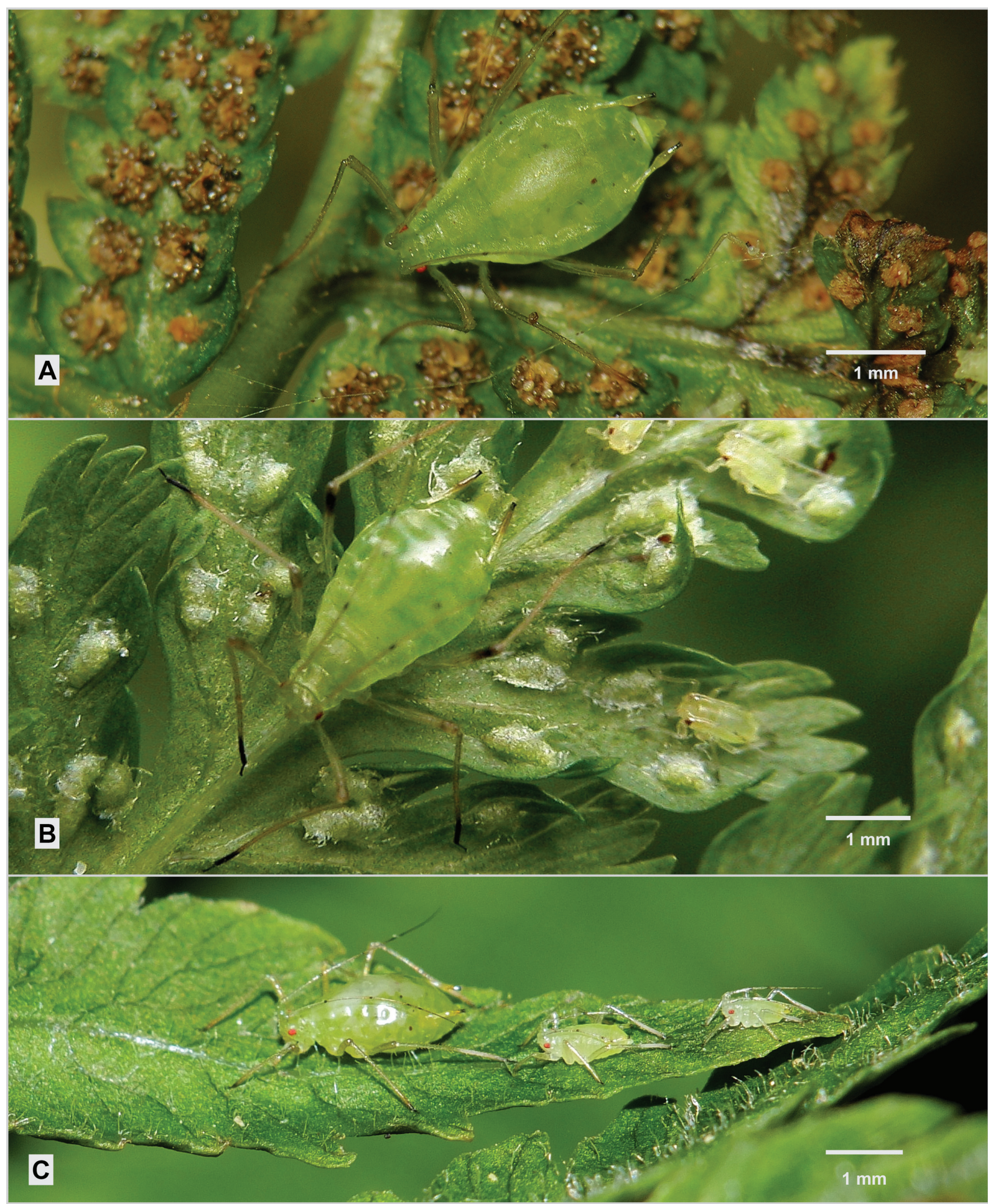

Fig. 34. Amphorophora ampullata Buckton, 1876. A. Aptera on Dryopteris carthusiana. B-C. Apterae and juveniles on Athyrium filix-femina (B) and Matteuccia struthiopteris (C), aptera in C parasitized. 
ALBRECHT A.C., Identification guide to Nordic aphids

\section{Macrosiphum dryopteridis (Holman, 1959)}

Fig. 35

\section{Diagnosis}

Aptera 2.5-4.2 mm, yellowish green (rarely bright green). Eyes black. Abd. dorsum sclerotised (but neither darkened nor distinctly glossy), segmental borders obliterated. Siphunculi slightly swollen distally. Ant. segment 3 with $0-10$ rhinaria. RIV+V less than $0.14 \mathrm{~mm}$. Holocyclic, monoecious. Shady places, parks, gardens, mixed and deciduous forests. Not ant-attended.

\section{Recorded hosts}

Athyriaceae: Athyrium distentifolium, A. filix-femina*; Cystopteridaceae: Gymnocarpium dryopteris, G. robertianum; Dennstaedtiaceae: Pteridium aquilinum; Dryopteridaceae: Dryopterix carthusiana*, D. cristata*, D. dilatata, D. filix-mas; Polypodiaceae: Polypodium vulgare; Thelypteridaceae: Phegopteris connectilis, Thelypteris palustris.

\section{Distribution}

F N S.

Macrosiphum ptericolens Patch, 1919

\section{Diagnosis}

Diagnosis based on Blackman \& Eastop (2006). Rostrum IV+V more than $0.14 \mathrm{~mm}$ long. Aptera 2.3$3.3 \mathrm{~mm}$, yellowish green to dark green. Siphunculi slender, tapering distally. Holocyclic, monoecious.

\section{Recorded host}

Dennstaedtiaceae: Pteridium aquilinum.

CBC. Lateral frontal tubercles with parallel or converging inner margins

Genus Aulacorthum Mordvilko, 1914

Aulacorthum solani (Kaltenbach, 1843)

Fig. 28

\section{Diagnosis}

Green with dark green patches in front of siphunculi. See p. 35, under BABB.

Genus Neomyzus van der Goot, 1915

Neomyzus circumflexus (Buckton, 1876)

Fig. 29

\section{Diagnosis}

Whitish, yellow or green with brown or black horse-shoe shaped marking. See p. 37, under BABB. 


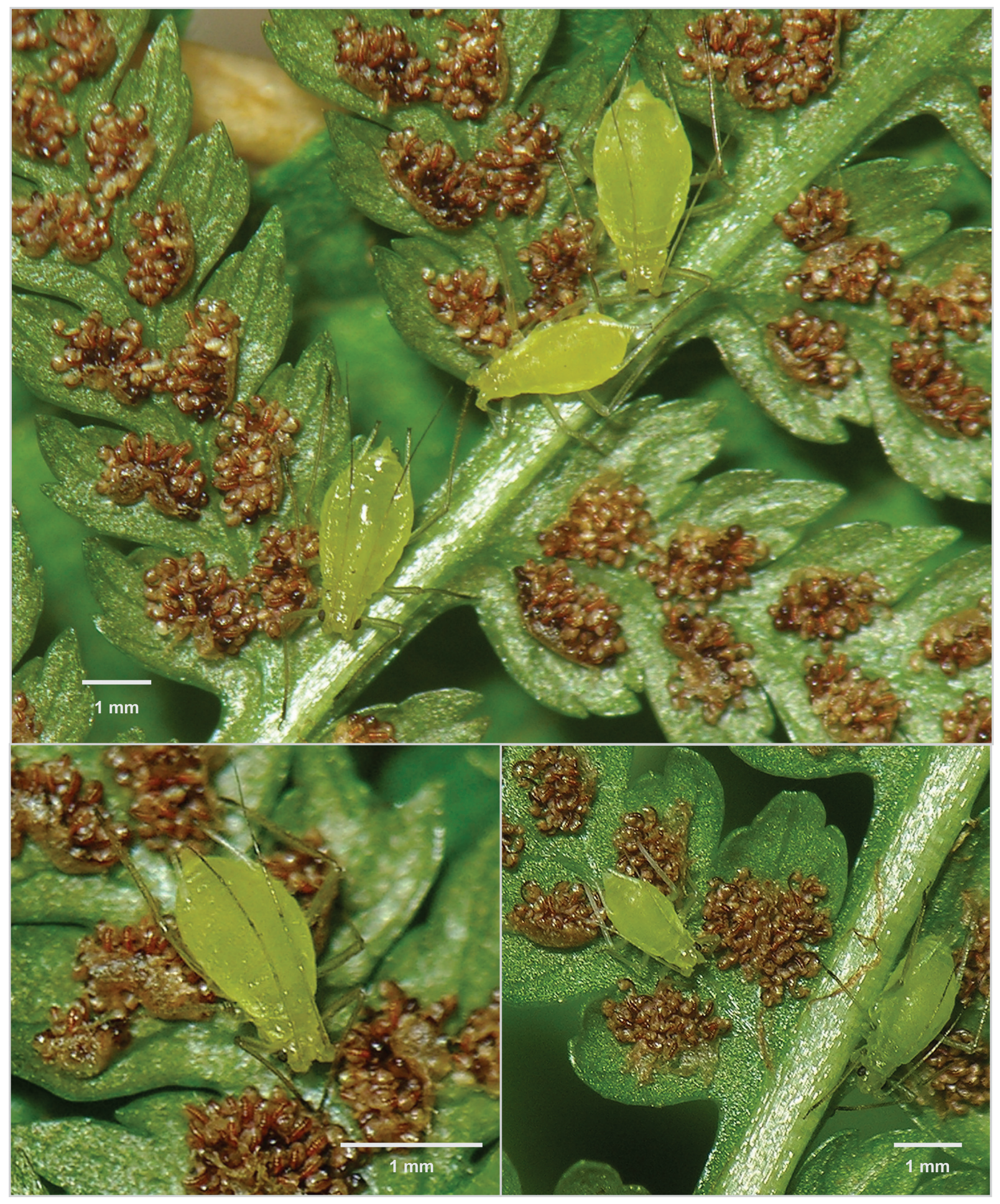

Fig. 35. Macrosiphum dryopteridis (Holman, 1959). Apterae on Athyrium filix-femina. 
ALBRECHT A.C., Identification guide to Nordic aphids

\section{Genus Myzus Passerini, 1860}

Myzus persicae (Sulzer, 1776)

Fig. 36

\section{Diagnosis}

Aptera 1.2-2.2 mm, almond-shaped, pale yellow to dirty yellow, olive, green, brownish, purple or reddish. Siphunculi twice as long as cauda or more, slightly swollen beyond middle. Dioecious,

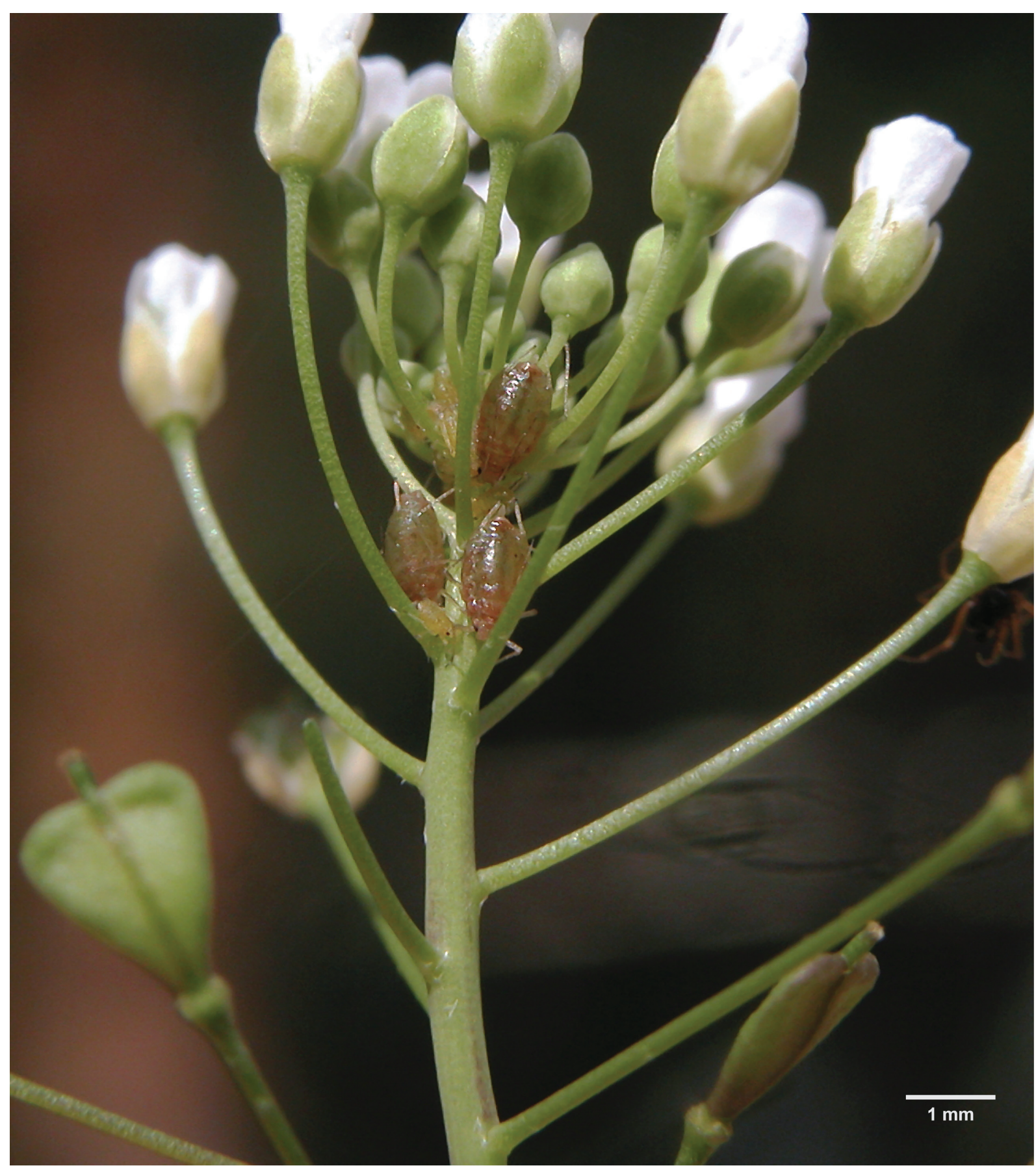

Fig. 36. Myzus persicae (Sulzer, 1776). Apterae and juveniles on Capsella bursa-pastoris. 
alternating between peach (Prunus persica) and plants of more than 40 families. Anholocyclic in the north and in the tropics. Usually in urban environments, also a common indoor pest.

\section{Recorded Pteridophyta host}

Pteridaceae: Adiantum sp.

\section{Distribution}

D F N S.

\section{Discussion}

Up to now, identification keys for aphids have been based on macerated specimens on microscopic slides, much of the emphasis being laid on measurements and indices based on them; in most cases only the ranges are given, without statistical parameters. Attempting to identify fresh or freeze-dried aphids using these keys may at first thought feel troublesome, but for the present that is the way we have to go. And it works, provided you have a good stereo microscope. Almost all of the characters described in the keys are well visible in unmacerated material, so slides need only exceptionally be made. And often a leg or antenna immersed in water on a slide is enough. One goal of this guide is to enhance the use of characters lost in the maceration process, many of which participate in the distinctiveness of the species and make it possible to identify as many of them as possible even in the field, although it is always advisable to look up the species in the literature and check the identification.

Most aphids are easily found by simply inspecting the plants, keeping the eyes open for abnormal growth, the presence of ants and other phenomena that may indicate the presence of aphids. Aphids associated with mosses are, however, generally considered rare and difficult to find. Aphids feeding on mycorrhizal conifer roots are readily revealed by the white wax wool they produce, but the genuine moss-feeders are almost impossible to spot in the field. Besides being small, they live hidden in the moss tussocks and are often cryptically coloured. In funnel samples they usually die before reaching the collection jar, which perhaps explains the seeming rarity of moss aphids. The best way of finding them is to dry all excess water from the moss, sieve it through a $1-2 \mathrm{~mm}$ mesh and study the sample alive under a stereo loupe. It seems quite safe to anticipate that, with the right methodology applied, moss aphids will prove to be surprisingly common throughout Northern Europe.

\section{Acknowledgements}

Among the numerous persons and institutions that have contributed to this guide, I wish to thank the Ministry of the Environment and the Finnish Museum of Natural History for allowing me to participate in the Putte Programme, which enabled me to study aphids full-time for five years, getting me started on the project, and for further support. Special thanks are due to my friend Jouni Issakainen for fruitful discussions and excursions leading to the discovery of numerous new interesting records of aphids. Above all, I want to thank my wife Margareta for fully accepting my work with these minute animals, for letting me set up a laboratory at home, and for time after time offering me a helping hand. My colleague Lauri Kaila kindly commented on the manuscript and suggested many valuable improvements. Thanks are also due to Dr Bill Blakemore of The Royal Entomological Society for allowing me to use copyrighted photographs.

\section{References}

Abenius J., Douwes P. \& Wahlstedt U. 2012. Steklar: Myror-getingar. Hymenoptera: FormicidaeVespidae. Nationalnyckeln, Uppsala. 
ALBRECHT A.C., Identification guide to Nordic aphids

Albrecht A. 1994. Freeze-drying techniques for preserving aphids (Homoptera, Aphidodea). Entomologica Fennica 5: 105-113.

Albrecht A. 2010. Atlas of the Aphids of Finland. Available from http://koivu.luomus.fi/elaintiede/ hyonteiset/tutkimus/kirvat/atlas.htm.

Blackman R.L. 2010. Aphids - Aphidinae (Macrosiphini). Handbooks for the Identification of British Insects 2 (7), The Royal Entomological Society, St Albans.

Blackman R.L. \& Eastop V.F. 1994. Aphids on the World's Trees. CAB International, Wallingford.

Blackman R.L. \& Eastop, V.F. 2000. Aphids on the World's Crops (2nd ed.). Wiley, Chichester.

Blackman R.L. \& Eastop V.F. 2006. Aphids on the World's Herbaceous Plants and Shrubs. (2 vols). Wiley, Chichester.

Blackman R.L. \& Eastop V.F. 2014. Aphids on the World's plants. Available from http://www. aphidsonworldsplants.info/ [accessed on 13 Feb. 2015].

Carter C. \& Danielsson R. 1991: Two spruce root aphids, Pachypappa vesicalis and Pachypappella lactea new to Britain with illustrated keys to the morphs from Picea roots. The Entomologist 112: 66-74.

Danielsson R. 1985. Polyviol as mounting medium for aphids (Homoptera: Aphidoidea) and other insects. Entomologica Scandinavica 15: 383-385.

Danielsson R. 1990a. The root-feeding generations of gall-making aphids of the genera Pachypappa Koch, Pachypappella Baker and Gootiella Tullgren. Acta Phytopathologica et Entomologica Hungarica 25: 77-88.

Danielsson R. 1990b. The life cycle of Gootiella tremulae Tullgren, with descriptions of all viviparous morphs and a redescription of Gootiella alba Shaposhnikov. Entomologica Scandinavica 20: 413-428.

Dransfield B. \& Brightwell B. 2015. Aphid genera. Available from http://influentialpoints.com/Gallery/ Aphid genera.htm [accessed on 30 Jun. 2015].

Favret C. 2015. Aphid Species File. Available from http://aphid.speciesfile.org/.

Heie O.E. 1980. The Aphidoidea of Fennoscandia and Denmark I. Mindaridae, Hormaphidae, Thelaxidae, Anoecidae and Pemphigidae. Fauna Entomologica Scandinavica 9. Scandinavian Science Press, Klampenborg.

Heie O.E. 1986. The Aphidoidea of Fennoscandia and Denmark III. Pterocommatinae and Aphidinae, Aphidini. Fauna Entomologica Scandinavica 17. E.J. Brill/Scandinavian Science Press, LeidenCopenhagen.

Heie O.E. 1992. The Aphidoidea of Fennoscandia and Denmark IV. Aphidinae. Part 1 of Macrosiphini. Fauna Entomologica Scandinavica.25. E.J. Brill/Scandinavian Science Press, Leiden-New YorkCopenhagen-Köln.

Heie O.E. 1994. The Aphidoidea of Fennoscandia and Denmark V. Aphidinae. Part 2 of Macrosiphini. Fauna Entomologica Scandinavica 28. E.J. Brill, Leiden-New York-Köln.

Heie O.E. 1995. The Aphidoidea of Fennoscandia and Denmark VI. Aphidinae. Part 3 of Macrosiphini and Lachnidae. Fauna Entomologica Scandinavica 31. E.J. Brill, Leiden-New York-Köln.

Heie O.E. 2004. Bladlus 1-2. Danmarks Fauna 87. Dansk Naturhistorisk Forening, København.

Hill M.O., Bell N., Bruggeman-Nannenga M.A., Brugués M., Cano M.J., Enroth J., Flatberg K.I., Frahm J.-P., Gallego M.T., Garilleti R., Guerra J., Hedenäs L., Holyoak D.T., Hyvönen J., Ignatov M.S., Lara F., Mazimpaka V., Muñoz J. \& Söderström L. 2006. An annotated checklist of the mosses of Europe and Macaronesia. Journal of Bryology 28: 198-267. http://dx.doi.org/10.1179/174328206X119998 
Holman J. 2009. Host Plant Catalog of Aphids. Palaearctic Region. Springer Science + Business Media B.V., Heidelberg.

Karlsson T. \& Agestam M. 2014. Checklista över Nordens kärlväxter. [Checklist of vascular plants of Scandinavia]. Available from http://www.euphrasia.nu/checklista/ [accessed on 30 Sep. 2014]

Pike K.S., Graf G., Foottit R.G., Maw H.E.L., von Dohlen C., Harpel J., Pantoja A., Emmert S. \& Hagerty A.M. 2012. Eriosomatine aphids (Hemiptera, Aphididae, Eriosomatinae) associated with moss and roots of conifer and willow in forests of the Pacific Northwest of North America. Canadian Entomologist 144: 555-576. http://dx.doi.org/10.4039/tce.2012.49

Stekolshchikov A.V. \& Shaposhnikov G.Kh. 1993. [Revision of the genus Muscaphis....] Entomologicheskoe Obozrenie 72: 333-344. [English translation (1994) Entomological Review 73: 42-54]

Manuscript received: 17 April 2015

Manuscript accepted: 11 August 2015

Published on: 21 October 2015

Topic editor: Koen Martens

Desk editor: Kristiaan Hoedemakers

Printed versions of all papers are also deposited in the libraries of the institutes that are members of the EJT consortium: Muséum National d'Histoire Naturelle, Paris, France; Botanic Garden Meise, Belgium; Royal Museum for Central Africa, Tervuren, Belgium; Natural History Museum, London, United Kingdom; Royal Belgian Institute of Natural Sciences, Brussels, Belgium; Natural History Museum of Denmark, Copenhagen, Denmark. 


\section{Appendix 1}

Summary of the host relationships of moss-feeding aphids of northern Europe. (Colours: Green = monoecious. Blue $=$ dioecious, on primary host (none in this table). Red $=$ dioecious, on secondary host. $*=$ my own records).

\section{BRYOPHYTA}

Sphagnaceae Dumort.

Sphagnum L.

$$
\begin{aligned}
& \text { Melaphis rhois } \\
& \text { Myzodium modestum }
\end{aligned}
$$

magellanicum Brid.

Pseudacaudella rubida*

recurvum H.H.Blom

Pseudacaudella rubida

Polytrichaceae Schwägr.

Atrichum P.Beauv.

undulatum (Hedw.) P.Beauv.

Decorosiphon corynothrix*

Muscaphis musci

Myzodium modestum

Polytrichastrum G.L.Sm.

formosum (Hedw.) G.L.Sm.

Decorosiphon corynothrix

Polytrichum Hedw.

commune Hedw.

Decorosiphon corynothrix*

Geoica utricularia* (occasionally on mosses)

Melaphis rhois

Muscaphis musci

Myzodium modestum*

Pseudacaudella rubida*

juniperinum Hedw.

Decorosiphon corynothrix

strictum Sull.

Decorosiphon corynothrix*

Grimmiaceae Arn.

Racomitrium Brid.

Myzodium modestum

lanuginosum (Hedw.) Brid.

Pseudacaudella rubida*

Dicranaceae Schimp.

Dicranum Hedw.

Muscaphis escherichi

Pseudacaudella rubida

Pottiaceae Schimp.

Barbula Hedw.

Muscaphis musci

Tortula Hedw.

muralis Hedw. 
Muscaphis musci

Bryaceae Schwägr.

Bryum Hedw.

Muscaphis musci

pallens Sw. ex anon.

Jacksonia papillata (see text)

Pohlia Hedw.

Muscaphis escherichi

Myzodium modestum

Rhodobryum (Schimp.) Limpr.

roseum (Hedw.) Limpr.

Muscaphis escherichi*

Mniaceae Schwägr.

Mniaceae s.lat.

Pseudacaudella rubida

Mnium Hedw.

hornum Hedw.

Muscaphis escherichi

Plagiomniaceae T.J.Kop.

Plagiomnium T.J.Kop.

affine (Blandow ex Funck) T.J.Kop.

Muscaphis escherichi*

rostratum (Schrad.) T.J.Kop.

Muscaphis escherichi

undulatum (Hedw.) P.Beauv.

Muscaphis escherichi

Muscaphis musci

Climaciaceae Kindb.

Climacium F. Weber \& D.Mohr

dendroides (Hedw.) F.Weber \& D.Mohr

Pseudacaudella rubida

Amblystegiaceae Kindb.

Amblystegium Schimp.

Muscaphis musci

Drepanocladus (Müll.Hal.) G.Roth

aduncus (Hedw.) Warnst.

Muscaphis cuspidata

Sanionia Loeske

uncinata (Schwägr.) Brid.

Pseudacaudella rubida*

Calliergonaceae (Kanda) Vanderp., Hedenäs, C.J.Cox \& A.J.Shaw

Calliergon (Sull.) Kindb.

Muscaphis musci

cordifolium (Hedw.) Kindb.

Pseudacaudella rubida*

Thuidiaceae Schimp.

Thuidium Schimp.

tamariscinum (Hedw.) Schimp.

Pseudacaudella rubida

Brachytheciaceae Schimp. 
Pseudoscleropodium (Limpr.) M.Fleisch. purum (Hedw.) M.Fleisch.

Muscaphis escherichi

Muscaphis musci

Eurhynchium Schimp.

Eurhynchium s.lat.

Muscaphis musci

striatum (Hedw.) Schimp.

Melaphis rhois

Cirriphyllum Grout

piliferum (Hedw.) Grout

Muscaphis escherichi*

Kindbergia Ochyra

praelonga (Hedw.) Ochyra

Muscaphis escherichi

Sciuro-hypnum Hampe

oedipodium (Mitt.) Ignatov \& Huttunen

(syn . Brachythecium curtum)

Pseudacaudella rubida*

Muscaphis escherichi*

Brachythecium Schimp.

albicans (Hedw.) Schimp.

Pseudacaudella rubida*

rivulare Schimp.

Muscaphis cuspidata*

rutabulum (Hedw.) Schimp.

Muscaphis musci

Brachytheciastrum Ignatov \& Huttunen velutinum (Hedw.) Ignatov \& Huttunen

Muscaphis musci

Pseudacaudella rubida

Hypnaceae Schimp.

Calliergonella Loeske

cuspidata (Hedw.) Loeske

Muscaphis cuspidata

Muscaphis escherichi

Muscaphis musci

Pseudacaudella rubida

Hyocomium Bruch \& Schimp.

armoricum (Brid.) Wijk \& Margad.

Jacksonia papillata (see text)

Melaphis rhois

Hypnum Hedw.

Melaphis rhois

cupressiforme Hedw.

Muscaphis escherichi

Jacksonia papillata (see text)

Ptilium De Not.

crista-castrensis (Hedw.) De Not.

Muscaphis escherichi 
Hylocomiaceae (Broth.) M.Fleisch.

Hylocomium Schimp.

splendens (Hedw.) Schimp.

Muscaphis musci

Pseudacaudella rubida*

Pleurozium Mitt

schreberi (Willd. ex Brid.) Mitt.

Muscaphis escherichi*

Pseudacaudella rubida*

Rhytidiadelphus (Limpr.) Warnst.

loreus (Hedw.) Warnst.

Muscaphis escherichi

squarrosus (Hedw.) Warnst.

Muscaphis escherichi

Decorosiphon corynothrix

Pseudacaudella rubida*

\section{Plagiotheciaceae}

Plagiothecium Schimp.

laetum Schimp.

Muscaphis escherichi 


\section{Appendix 2}

Summary of the host relationships of the Northern European aphids feeding on horsetails and ferns. $($ Colours: Green $=$ monoecious. Blue $=$ dioecious, on primary host $($ none in this table $)$. Red $=$ dioecious, on secondary host. $*=$ my own records)

\section{PTERIDOPHYTA}

EQUISETALES DC. ex Bercht. \& J. Presl

Equisetaceae Michx. ex DC.

Equisetum L.

Myzus cerasi

arvense $\mathrm{L}$.

Aulacorthum circumflexum*

Macrosiphum equiseti

Paracletus cimiciformis (exceptionally?)

fluviatile L.

Aulacorthum solani*

pratense Ehrh.

Aphis equiseticola

Macrosiphum equiseti

sylvaticum $\mathrm{L}$.

Aphis equiseticola

Aphis gossypii

Macrosiphum equiseti*

Rhopalosiphum padi (exceptionally)

Sitobion avenae (exceptionally)

Sitobion fragariae (exceptionally)

telmateia Ehrh.

Macrosiphum equiseti

SALVINIALES Bartl.

Marsileaceae Mirb.

Marsilea L.

quadrifolia $\mathrm{L}$.

Rhopalosiphum nymphaeae

strigosa Willd.

Rhopalosiphum nymphaeae

Salviniaceae Martinov

Azolla Lam.

caroliniana Willd.

Rhopalosiphum nymphaeae

filiculoides Lam.

Rhopalosiphum nymphaeae

Salvinia Ség.

auriculata Aubl.

Neomyzus circumflexus

Rhopalosiphum nymphaeae

natans (L.) All.

Rhopalosiphum nymphaeae

POLYPODIALES Link

Dennstaedtiaceae Lotsy 
Dennstaedtia Bernh.

Amphorophora ampullata

Idiopterus nephrelepidis

Pteridium Gled. ex Scop.

aquilinum (L.) Kuhn

Amphorophora ampullata

Macrosiphum dryopteridis

Macrosiphum ptericolens

Pteridaceae E. D. M. Kirchn.

Adiantum L.

Neomyzus circumflexus*

Idiopterus nephrelepidis

Myzus persicae

capillus-veneris L.

Aulacorthum solani

Pteris L.

Idiopterus nephrelepidis

Cystopteridaceae Shmakov

Cystopteris Bernh.

montana (Lam.) Desv.

Amphorophora ampullata

Gymnocarpium Newman

dryopteris (L.) Newman

Amphorophora ampullata

Macrosiphum dryopteridis

robertianum (Hoffm.) Newman

Macrosiphum dryopteridis

Aspleniaceae Newman

Asplenium L.

Amphorophora ampullata

Neomyzus circumflexus

adiantum-nigrum $\mathrm{L}$.

Idiopterus nephrelepidis

ruta-muraria $\mathrm{L}$.

Idiopterus nephrelepidis

scolopendrium $\mathrm{L}$.

Idiopterus nephrelepidis

trichomanes $\mathrm{L}$.

Aulacorthum solani

Thelypteridaceae Pic.Serm.

Phegopteris (C. Presl) Fée

connectilis (Michx.) Watt

Amphorophora ampullata

Macrosiphum dryopteridis

Thelypteris Schmidel

palustris Schott

Amphorophora ampullata

Macrosiphum dryopteridis

Onocleaceae Pic. Serm.

Matteuccia Tod. 
struthiopteris (L.) Tod.

Amphorophora ampullata*

Neomyzus circumflexus

Onoclea L.

Amphorophora ampullata

Blechnaceae Newman

Blechnum L.

Idiopterus nephrelepidis

Athyriaceae Aston

Athyrium Roth

distentifolium Tausch ex Opiz

Macrosiphum dryopteridis

Macrosiphum lapponicum

filix-femina (L.) Roth

Amphorophora ampullata*

Aulacorthum solani*

Macrosiphum dryopteridis*

Dryopteridaceae Herter

Cyrtomium C. Presl

falcatum (L.f.) C. Presl

Neomyzus circumflexus

Idiopterus nephrelepidis

Dryopteris Adans.

carthusiana (Vill.) H. P. Fuchs

Amphorophora ampullata*

Macrosiphum dryopteridis*

cristata (L.) A. Gray

Macrosiphum dryopteridis*

dilatata (Hoffm.) A. Gray

Amphorophora ampullata

Macrosiphum dryopteridis

filix-mas (L.) Schott

Amphorophora ampullata

Macrosiphum dryopteridis

Polystichum Roth

Amphorophora ampullata

lonchitis (L.) Roth

Neomyzus circumflexus

Nephrolepidaceae Pic.Serm.

Nephrolepis Schott

Neomyzus circumflexus

exaltata (L.) Schott

Idiopterus nephrelepidis

Polypodiaceae J. Presl \& C. Presl

Polypodium L.

vulgare $\mathrm{L}$.

Neomyzus circumflexus

Aulacorthum solani

Macrosiphum dryopteridis 